\title{
Consensus Report
}

\section{Fetal Bovine Serum (FBS): Past - Present - Future}

Jan van der Valk ${ }^{1}$, Karen Bieback ${ }^{2}$, Christiane Buta ${ }^{3}$, Brett Cochrane ${ }^{4}$, Wilhelm G. Dirks ${ }^{5}$, Jianan Fu ${ }^{6}$, James J. Hickman ${ }^{7}$, Christiane Hohensee ${ }^{8}$, Roman Kolar ${ }^{9}$, Manfred Liebsch ${ }^{10}$, Francesca Pistollato ${ }^{11}$, Markus Schulz ${ }^{12}$, Daniel Thieme ${ }^{13}$, Tilo Weber $^{9}$, Joachim Wiest $^{14}$, Stefan Winkler ${ }^{15}$ and Gerhard Gstraunthaler ${ }^{16}$

${ }^{1}$ The 3Rs-Centre Utrecht Life Sciences, Utrecht University, Utrecht, The Netherlands; ${ }^{2}$ Institute of Transfusion Medicine and Immunology, Medical Faculty Mannheim, Heidelberg University, Mannheim, Germany; ${ }^{3}$ SET Foundation, Frankfurt a. M., Germany; ${ }^{4}$ Animal Free Research UK, Hitchin, Hertfordshire, UK; ${ }^{5}$ Leibniz-Institute DSMZ, German Collection of Microorganisms and Cell Cultures, Braunschweig, Germany; ${ }^{6}$ PAN-Biotech Ltd, Aidenbach, Germany; ${ }^{7}$ NanoScience Technology Center, University of Central Florida, Orlando, FL, USA; ${ }^{8}$ Invitro+Jobs, The Federal Association of People for Animal Rights Germany (PARG), Aachen, Germany; ${ }^{9}$ Animal Welfare Academy, German Animal Welfare Federation, Neubiberg, Germany; ${ }^{10}$ Königs Wusterhausen, Germany; ${ }^{11}$ Directorate F - Health, Consumers and Reference Materials, Joint Research Centre, Ispra, VA, Italy; ${ }^{12}$ BASF SE, Experimental Toxicology and Ecology, Ludwigshafen, Germany; ${ }^{13}$ Department of Ophthalmology, University of Erlangen-Nürnberg, Erlangen, Germany; ${ }^{14}$ cellasys GmbH, Kronburg, Germany; ${ }^{15}$ Institute of Applied Cell Culture (IAZ), Munich, Germany; ${ }^{16}$ Division of Physiology, Medical University Innsbruck, Innsbruck, Austria

\begin{abstract}
Summary
The supplementation of culture medium with fetal bovine serum (FBS, also referred to as "fetal calf serum") is still common practice in cell culture applications. Due to a number of disadvantages in terms of quality and reproducibility of in vitro data, animal welfare concerns, and in light of recent cases of fraudulent marketing, the search for alternatives and the development of serum-free medium formulations has gained global attention. Here, we report on the $3^{\text {rd }}$ Workshop on FBS, Serum Alternatives and Serum-free Media, where regulatory aspects, the serum dilemma, alternatives to FBS, case-studies of serum-free in vitro applications, and the establishment of serum-free databases were discussed.

The whole process of obtaining blood from a living calf fetus to using the FBS produced from it for scientific purposes is de facto not yet legally regulated despite the existing EU-Directive 2010/63/EU on the use of animals for scientific purposes. Together with the above-mentioned challenges, several strategies have been developed to reduce or replace FBS in cell culture media in terms of the 3Rs (Refinement, Reduction, Replacement). Most recently, releasates of activated human donor thrombocytes (human platelet lysates) have been shown to be one of the most promising serum alternatives when chemically-defined media are not yet an option. Additionally, new developments in cell-based assay techniques, advanced organ-on-chip and microphysiological systems are covered in this report. Chemically-defined serum-free media are shown to be the ultimate goal for the majority of culture systems, and examples are discussed.
\end{abstract}

Keywords: serum-free, cell culture, databases, 3Rs, replace

\section{Introduction}

\subsection{Workshops on the replacement of FBS}

This is the report of the $3^{\text {rd }}$ workshop devoted to the replacement of fetal bovine serum (FBS) in cell and tissue culture methods. The $1^{\text {st }}$ workshop, held in Utrecht, The Netherlands, in 2003 (van der Valk et al., 2004) was initiated after publication of a comprehensive report on pain and distress experienced by fetal

Received May 10, 2017;

Accepted August 8, 2017;

Epub August 9, 2017;

doi:10.14573/altex.1705101 calves during harvesting of their blood for production of FBS (Jochems et al., 2002). The main goal was to create awareness, to propose procedures to avoid pain and distress, and to discuss possibilities to reduce or replace the use of FBS in cell culture media. A second workshop was organized in Copenhagen, Denmark, in 2009 to discuss current in vitro methods devoid of FBS or other animal components and strategies to develop serum-free media (van der Valk et al., 2010). 
Since then, several new developments have occured. In 2010, the revised EU Directive 2010/63/EU on the protection of animals used for scientific purposes (EU, 2010) was issued, also covering fetal forms of mammals. Furthermore, in recent years there have been increased efforts towards the establishment of human platelet lysates as alternatives to FBS for use as a cell culture supplement (Bieback, 2013; Burnouf et al., 2016; Gstraunthaler et al., 2015; Hemeda et al., 2014; Shih and Burnouf, 2015). In spring 2013, a severe case of fraudulent blending of FBS batches came to public attention (Gstraunthaler et al., 2013, 2014). Also, successful serum-free applications that had been developed for primary neuronal cell systems to approximate cerebrospinal fluid (CSF) (Schaffner et al., 1995) were extended to other cell types for microphysiological systems and organon-chip technologies (Marx et al., 2016; Sung et al., 2013), one of which is completely serum-free (Oleaga et al., 2016). These promising developments gave reason to organize a $3^{\text {rd }}$ workshop on FBS, Serum Alternatives and Serum-free Media.

The following topics were discussed with experts in the field at this workshop: regulatory aspects (Section 2), the serum dilemma (Section 3), alternatives to FBS (Section 4), case-studies of serum-free in vitro applications (Section 5), and serum-free databases (Section 6).

\subsection{Problems of FBS use}

Fetal bovine serum (FBS) was introduced to stimulate cellular growth in cell and tissue culture by Theodore Puck in the late 1950s (Puck et al., 1958). It later turned out that FBS contains essential components for cell proliferation and maintenance such as hormones, vitamins, transport proteins, trace elements, spreading and growth factors (Maurer, 1986; Brunner et al., 2010). Since Puck's discovery, FBS has been used as a universal supplement in culture media for human and animal (including insect) cells in research, biotechnology and pharmaceutical manufacturing. Although bovine sera of alternative origin are available, like newborn calf serum, calf serum, and donor bovine serum, fetal bovine (fetal calf) serum (FBS/FCS) is most widely used due to its low content of immunoglobulins and complement factors (Gstraunthaler and Lindl, 2013).

FBS is collected from the blood of unborn calves (fetuses) at any developmental stage of the last two-thirds of gestation, which are mostly accidently discovered when slaughtering pregnant cows (Jochems et al., 2002). It is calculated that approximately $8 \%$ of cows in the slaughter line are pregnant at different stages of gestation. Recent figures estimate that about 800,000 liters of FBS are produced annually worldwide, corresponding to 2,000,000 bovine fetuses, with numbers still increasing (Brindley et al., 2012).

The use of FBS is associated with a number of problematic issues. In addition to scientific disadvantages such as unknown exact composition, seasonal and geographical lot-to-lot variability (Baker, 2016b), and unintended interaction with test substances (Groothuis et al., 2015; Kramer et al., 2009), which can lead to unexpected or undesired outcomes, serious safety concerns for laboratory personnel in terms of endotoxins, mycoplasma and viral contaminants or prion proteins (Dormont, 1999; Wessman and Levings, 1999; Hawkes, 2015), as well as ethical concerns about fetal distress (van der Valk et al., 2004), and unpredictable shortages in global supply (Brunner et al., 2010; Gstraunthaler, 2003) have been raised with regard to the use of FBS.

Some of the scientific problems found to be caused by the use of FBS include the following: It has been shown that FBS can suppress transforming growth factor (TGF)- $\beta 1$-induced chondrogenesis in fibroblast-like type-B synoviocytes, inhibiting glycosaminoglycan and type II collagen production (Bilgen et al., 2007). FBS was also found to induce a more differentiated and less stable transcriptional profile in human bone marrow mesenchymal stem cells (hMSCs) compared to autologous (human) serum, as shown by genome-wide microarray analysis, which indicated upregulation of genes involved in cell cycle inhibition particularly in late passaged hMSCs cultured with FBS (Shahdadfar et al., 2005). Furthermore, high molecular weight proteins, such as albumin and globulins contained in serum, are a non-physiological environment for somatic cells, which normally reside in interstitial spaces.

Batch-to-batch variability related to variations in the concentrations of serum components and their biological activity can ultimately lead to experimental variability and limit inter-laboratory reproducibility, particularly for the culture, expansion and differentiation of primary cells, representing a major cost associated with cell culture (Usta et al., 2014). Owing to the questionable reproducibility of models that rely on FBS, their use for regulatory purposes is debated (Brindley et al., 2012; Mannello and Tonti, 2007; Tekkatte et al., 2011). For this reason, serum-supplemented media should be avoided wherever possible, and chemically-defined media preferred (see also Section 2, and van der Valk et al., 2010).

To maximize the collection of blood for FBS production per calf fetus, the blood is collected by syringe from the beating heart. According to the precautionary principle, one has to assume that there is the potential for conscious suffering during a large period of fetal development, which means that the fetal calves may consciously experience pain and discomfort during collection for FBS (Mellor et al., 2005; van der Valk et al., 2004), including being extricated from their mother's corpse, puncture of their heart and the blood withdrawal itself, which leads to their death (Jochems et al., 2002). Although recommendations have been made to avoid the suffering of the calves, there is only limited indication that these are being applied (van der Valk et al., 2004).

The employment of FBS-free media reduces animal suffering and may lead to more reproducible in vitro methods, some of which are developed to replace or reduce animal experiments. It therefore also contributes to the replacement, reduction and refinement of animal experiments (3Rs) (Balls et al., 1995).

Thus, safety, scientific, and ethical aspects are incentives to develop and use (fetal bovine) serum-free media.

\section{Regulatory aspects}

In recent years, several pieces of European legislation have addressed and encouraged the use of alternative (non-animal) methods, such as Regulation No 1907/2006 on the Registration, Eval- 
Tab. 1: Test methods described in OECD Test Guidelines (TG) and the corresponding cell culture media

\begin{tabular}{|c|c|}
\hline Test methods in OECD TG 431 & Cell culture medium \\
\hline EpiDerm ${ }^{\mathrm{TM}}$ (EPI-200-SCT) & Chemically-defined medium (Liebsch et al., 2000) \\
\hline SkinEthic ${ }^{\mathrm{TM}} \mathrm{RHE}$ & Chemically-defined medium (De Brugerolle, 2007) \\
\hline epiCS $^{\circledR}$ (previously named EST-1000) & Serum-free and chemically-defined medium (CellSystems, 2012; Sarmento, 2015) \\
\hline EpiSkin TM SM & 10\% FBS (Flamand et al., 2006; Rougier and Schaefer, 1998) \\
\hline Test methods in OECD TG 439 & Cell culture medium \\
\hline EpiDerm $^{\mathrm{TM}}$ (EPI-200-SIT) & Chemically-defined medium (Liebsch et al., 2000) \\
\hline SkinEthic ${ }^{\mathrm{TM}} \mathrm{RHE}$ & Chemically-defined medium (De Brugerolle, 2007) \\
\hline LabCyte EPIMODEL24 SIT & $5 \%$ FBS (Katoh et al., 2009, 2010) \\
\hline EpiSkin ${ }^{\mathrm{TM}}$ SM & 10\% FBS (Flamand et al., 2006; Rougier and Schaefer, 1998) \\
\hline Test methods in OECD TG 492 & Cell culture medium \\
\hline EpiOcularTM EIT & Serum-free medium (Sheasgreen et al., 1996) \\
\hline
\end{tabular}

uation, Authorisation and Restriction of Chemicals (REACH) (EC, 2006), Regulation No 1223/2009 on cosmetic products (EC, 2009), and EU Directive No 2010/63/EU on the protection of animals used for scientific purposes (EU, 2010).

In particular, the Directive states that the use of animals in toxicology testing and biomedical research should be ended as soon as scientifically feasible to do so. While the Directive does not directly cover the issues underlying fetal serum withdrawal, the following is specified under Reason 9 of the Preamble: "this Directive should also cover fetal forms of mammals, as there is scientific evidence showing that such forms in the last third of the period of their development are at an increased risk of experiencing pain, suffering and distress, which may also negatively affect their subsequent development. Scientific evidence also shows that procedures carried out on embryonic and fetal forms at an earlier stage of development could result in pain, suffering, distress or lasting harm, should the developmental forms be allowed to live beyond the first two thirds of their development".

Sera are sourced from a wide geographic range of countries, including members of the European Union (Biowest, 2016), where this Directive applies. Considering Article 1 and $3^{1}$, it can be concluded that the harvesting of FBS from live bo- vine fetuses in the last third of their development, if it takes place on EU territory, is thus a procedure under the Directive because the serum is clearly used for scientific purposes and is extracted from a living animal. Therefore, the procedures would need to undergo a project review and authorization by a competent authority. Were the calves killed before the extraction of the blood, this would be a different case. The legal dilemma concerning this is the fact that a proper cost-benefit analysis, as required for a procedure under the Directive, would be difficult. The cost, i.e., the suffering and death of the animals involved, is completely separated from the potential, but largely questionable, benefit which might result from the continued use of FBS. Such a cost-benefit analysis would only be possible in a scenario in which the harvested FBS from specific animals would be exclusively supplied to one specific research institute for a distinct research project. Therefore, the particular benefit of the bleeding of one individual fetus remains unknown so that at present any cost-benefit considerations would not be demonstrated.

Moreover, in 2008, the ECVAM Scientific Advisory Committee (ESAC) advocated the use of non-animal-derived supplements for in vitro studies wherever possible and stated that "for methods forwarded to ECVAM for validation/pre-valida-

\footnotetext{
${ }^{1}$ Excerpt of Directive 2010/63/EU (EU, 2010).

Article 1

Subject matter and scope

2. This Directive shall apply where animals are used or intended to be used in procedures, or bred specifically so that their organs or tissues may be used for scientific purposes.

3. This Directive shall apply to the following animals:

(ii) fetal forms of mammals as from the last third of their normal development;"

Article 3

Definitions

1. 'procedure' means any use, invasive or non-invasive, of an animal or experimental or other scientific purposes, with known or unknown outcome, or educational purposes, which may cause the animal a level of pain, suffering, distress or lasting harm equivalent to, or higher than, that caused by the introduction of a needle in accordance with good veterinary practice.[...] but excludes the killing of animals solely for the use of their organs or tissue;"
} 
tion where (the use of non-animal alternatives to serum) is not fulfilled a justification for future use must be provided, including measures taken to seek non-animal alternatives to (FBS)" (ESAC, 2008). The drawbacks of using serum and advice to replace it with chemically-defined (serum-free) media are also mentioned in the Good Cell Culture Principles (GCCP) issued by EURL ECVAM in 2005 (Coecke et al., 2005), and more recently in the workshop report on GCCP for stem cells and stem-cell-derived models (Pamies et al., 2017). Also, the test guidelines no. 431, 439 and 492 (OECD, 2015a,b, 2016) for the testing of chemicals published by the Organisation for Economic Co-operation and Development (OECD) include chemically-defined/serum-free cell culture media in several in vitro test methods for skin corrosion, skin irritation and eye irritation testing, as listed in Table 1.

The US Food and Drug Administration (FDA) has also indicated that the use of animals should be minimized and replacements utilized, including use of equivalent in vitro methods, when applicable (Brindley et al., 2012; Mannello and Tonti, 2007; Tekkatte et al., 2011). And, last but not least, for clinical-scale or Good Manufacturing Practice (GMP)-compliant manufacturing of cell-based products (advanced therapy medicinal products (ATMPs)) regulatory authorities request the replacement of FBS (EMA, 2011).

\section{The serum dilemma}

\subsection{The serum market}

FBS is a by-product of the beef industry and its production is dependent on a number of external factors, like weather conditions (e.g., climate changes with drought or flood) or changes in beef consumption (e.g., switch to poultry) that are hard to control (Brindley et al., 2012). The increasing use of FBS in cell culture, research, diagnostics and pharmaceutical manufacturing has led to a global business traded on the stock market. The opacity, loose regulation and near cartel-like situation of the FBS market opens doors for wrongdoing, misconduct and even fraud (Gstraunthaler et al., 2014; Hodgson, 1991, 1993, 1995).

Exact volumes of global production of FBS and availability, respectively, as well as of the worldwide demand are still unknown, which may create opportunities for abuse, mislabeling and adulteration of FBS. In 1994, it was reported that approximately 30,000 1 of "New Zealand" serum were sold worldwide. However, only 15,000 1 of high-quality FBS were collected annually in New Zealand (Hodgson, 1995). In spring 2013, another case of fraud occurred, where FBS from a global supplier appeared to be blended with bovine serum albumin, water and growth promoting additives. A US FDA investigation showed that 143 batches of FBS (from the years 2008 to 2013), with a total volume of approximately 280,0001 , were affected. This incident might have had a substantial impact on the results of thousands of cell culture experiments. Also, quality and yield of cell culture-based biotechnology products, diagnostics and vaccines may have been affected (Gstraunthaler et al., 2014). As a very visible result of this turmoil in the serum market, the prices for FBS skyrocketed in 2015 from about $€ 80$ per $500 \mathrm{ml}$ up to $€ 1,200$ per $500 \mathrm{ml}$.

Due to these latest incidents, the geographical origin, sourcing, and traceability of FBS became an issue (Siegel and Foster, 2013; Versteegen, 2016; ISIA, 2016). A crucial element of FBS quality and purity assurance lies in the traceability of the raw product. Purity-checks and back tracing of batches of FBS to the collection sites and countries of origin, respectively, can now easily be accomplished by stable isotope analysis (Ehleringer et al., 2008; Versteegen, 2016).

Therefore, in addition to ethical and scientific aspects, risk of adulterated composition and unstable prices give further reason to move away from the use of serum in general, and FBS in particular.

\subsection{Reliability of scientific data using in vitro models, role of FBS}

The use of FBS in routine cell culture is an embedded practice that is taught in almost every cell culture training. In the spirit of "never change a winning team" there appears, from a technical point of view, no need to change this methodology. Cell culture methods are intended to be highly standardized procedures to investigate changes in viability, growth and cell communication by varying single parameters such as adding chemicals of interest. However, FBS is a variable and undefined medium component with a complex composition that is still not fully understood. It may contain generally unpredictable factors, which might change between batches, for maintenance of the cell culture that impact upon responses.

One example for such problems caused by FBS comes from translational research on cancer, where tumor cell lines are often used to model carcinogenesis. An indispensable condition for fast implementation of new clinical approaches is that researchers worldwide use identical models to generate results that can validate each other's findings. Global Biological Resource Centres (BRCs) are equipped with authentication standards to ensure an optimal use of these models (Almeida et al., 2016; Barallon et al., 2010; Capes-Davis and Neve, 2016; Freedman et al., 2015). A recent survey revealed a reproducibility crisis in biomedical science, since more than $70 \%$ of researchers have failed to reproduce published experiments (Baker, 2016a), which in cancer research can be partly attributed to the use of different batches of FBS, as will be discussed below. Furthermore, the fast-growing knowledge from intra-tumor across inter-patient to intra-cell line heterogeneities demands a comprehensive maintenance and safeguarding of a sufficient number of models to represent the genomic diversity observed across human cancers.

The qualitative and quantitative variations of FBS batches can cause selection and subclonal outgrowth of tumor cell lines. Heterogeneity of primary tumor cells represents one of the major disadvantages compared to continuous cell lines, since it is proposed that cell lines originate from a single neoplastic cell. Recently, the presence of two clones in one cell line has been described, indicating clonal evolution within a cell culture population (Quentmeier et al., 2013).

BRCs generally use high quality FBS, sufficient for proliferation of the majority of the continuous cell lines. FBS lot 
charge exchanges at cell banks require extensive testing on a panel of cell lines representing different tissues and applications for a time period of at least 2 weeks, since one may not see the differentiating or apoptotic effects of the new FBS lot immediately after use. Intra-cellular stores could initiate proliferation and falsify the results in short term testing, and nutritional deficiencies could cause cell lines to lose or gain genetic and phenotypic functions. The worst-case scenario is that bottlenecking selection procedures for the effects of newly purchased FBS batches on the different cell types are visible or measurable only in the rarest cases. Elimination of ancestral clones by sequential selection, possibly by unsuitable FBS charges on sophisticated cell culture, could result in replacement by novel clones that are genetically still identical but equipped with modified features (Kasai et al., 2016). A recent comparison of experimental methods for reproducible pharmacogenomic profiling of cancer cell line panels highlighted evidence that even the amount of FBS in growth media could have an impact (Haverty et al., 2016).

An additional potential issue is associated with the use of charcoal to strip out endogenous hormones, growth factors and cytokines from serum. Charcoal stripped FBS is commonly used to study the effects of steroid hormones in vitro, but is prone to a high lot-to-lot variability (Sikora et al., 2016). A 2005 study found that charcoal stripping of FBS unexpectedly affected the commitment of osteoprogenitor KS483 cells, highly stimulating adipogenesis compared to normal FBS containing medium, which drives KS483 cells to differentiate into only osteoblasts (Dang and Lowik, 2005).

As a conclusion, there is an unmistakable demand for chemically-defined media for achieving data reliability and for overcoming the reproducibility crisis caused by FBS charges of non-definable qualities (Baker, 2016b; van der Valk et al., 2004, 2010).

\section{Alternatives to FBS}

In light of the previously mentioned scientific, consistency, ethical, and supply challenges, the search for alternatives to FBS, and serum derived from animals in general, has become a major goal in the field of cell and tissue culture research (Brunner et al., 2010; van der Valk et al., 2010).

Several approaches, like serum-free media, protein-free media, animal-derived component free media (xeno-free media) and chemically-defined media are being developed and applied and were discussed in detail in the previous workshop (van der Valk et al., 2010).

The first widespread use of serum-free medium was developed for primary neuronal cultures to more closely approximate cerebrospinal fluid (CSF), which normally contains less than $0.001 \%$ protein compared to approximately $8 \%$ in serum (Busher, 1990). This was extended to create the first defined system where all the medium components, including the culture vessel surface modifications, in addition to the medium were well-defined (Schaffner et al., 1995). This technology has now been extended to include cardiomyocytes (Das et al., 2004; Natara- jan et al., 2006, 2011), hippocampal neurons (Varghese et al., 2009), motoneurons (MNs) (Das et al., 2003, 2007a; Guo et al., 2010), sensory neurons (Guo et al., 2013; Rumsey et al., 2010), muscle (Das et al., 2006, 2007b, 2009; Varghese et al., 2009), neuromuscular junction formation (Chen et al., 2011; Guo et al., 2010; Smith et al., 2013), and a multi-organ system with functional readout (Oleaga et al., 2016).

There are now also some examples that demonstrate that adaptation to FBS-free cell culture does not have a major impact on the robustness of cell culture systems or on the scientific outcome of the studies (Jukić et al., 2016; Oleaga et al., 2016; Rumsey et al., 2013; Stancescu et al., 2015). However, chemically-defined serum-free media have not yet been developed for every cell line or primary culture at this time (Bjare, 1992; Even et al., 2006; Gstraunthaler, 2003; Brunner et al., 2010). Additional complicating factors, such as the surface on which the cells are grown and cell preparation, might also have an effect on cell phenotypes and reproducibility.

Because of these facts, a universal chemically-defined serum-free culture medium is unfortunately not (yet) available and appears unrealistic given the high specific demand of different cell types as described below. However, with an understanding of the interplay of the factors, models using a serum-free medium have been developed for several cell types (Esch et al., 2016).

\subsection{Human platelet lysates (hPL) \\ 4.1.1 hPL in animal and human cell cultures}

The long and winding road to finding alternatives to FBS (van der Valk et al., 2004, 2010) may be reaching its destination with the development of lysates of blood platelets or thrombocytes. Early reports in the 1980s asked why plasma and serum have different abilities to promote in vitro growth of cultured cells (Gospodarowicz and Ill, 1980) and found that serum, but not plasma, contains mitogenic factors (Balk et al., 1981). During the clotting process, thrombocytes are activated to release an array of $\alpha$-granule factors that initiate and maintain blood clotting and promote wound healing (Blair and Flaumenhaft, 2009; Burnouf et al., 2013). Most of these factors also promote cell attachment, growth and proliferation in vitro (Barnes et al., 1987) (Fig. 1).

Already in 1980, human platelet lysate (hPL) or other platelet-derived factors had been introduced as promising sources of growth promoting factors for cultured cells, established cell lines, tumor cells or articular chondrocytes (Choi et al., 1980; Eastment and Sirbasku, 1980; Hara et al., 1980). hPL is obtained by freeze-thawing human platelet concentrates; platelet releasates (hPR) are the growth factors released after activating platelets from platelet concentrates (Bieback et al., 2009).

With hPL, bulk thrombocytic growth factors are added to basal culture media, providing a human-based, xeno-free culture system (Gstraunthaler et al., 2015; Rauch et al., 2011). hPL are superior over other human-based alternatives for several reasons. Firstly, the source of hPL, human donor platelet concentrates, are easily available due to their short shelf life for transfusion purposes (see below). Secondly, hPL are low protein extracts of thrombocytic growth factors, in contrast to other hu- 
man serum-derived alternatives (Bieback, 2013; Burnouf et al., 2016; Gstraunthaler et al., 2015; Hemeda et al., 2014; Shih and Burnouf, 2015).

Platelet concentrates are typically manufactured for transfusion purposes. This is therefore a well-recognized, safe and clinically tested, high quality product from certified blood donation centers. Platelet concentrates can either be derived from pooled buffy coat (typically 4 donors) or be apheresis-derived (Fekete et al., 2012). As platelet concentrates are obtained for the transfusion of patients with platelet deficiency, an ethical issue would arise if fresh platelet concentrates were used instead for cell culture. However, platelet concentrates expire for transfusion purposes after a maximum shelf-life of 5 days, after which they can still be used as a cell culture supplement. Since platelet concentrates are stored at room temperature, there is a risk of bacterial contamination (Pietersz et al., 2014). Thus, the shelf-life (in Germany) is currently restricted to 4 days and can be extended to 5 days in case of negative bacterial testing. One current strategy to manage this risk of potential infection is quarantine storage, although this mainly controls for the risk of donor infection. Concentrates are stored until the donors have donated blood for a second time and have again tested negative for infectious markers. A second approach, which is currently being investigated, is the use of pathogen reduction/inactivation (Castiglia et al., 2014; Jonsdottir-Buch et al., 2015; Shih et al., 2011; Ståhle et al., 2010).

hPL and hPR differ with respect to their growth factor content. Whereas the freeze-thaw lysis to generate hPL releases all the factors contained in the platelets, including the cargo of lysosomes, dense granules and $\alpha$-granules, hPR only contains factors released in response to thrombocyte activation (the classical clotting process), mainly a cargo of $\alpha$-granules. Also, the composition of growth factors may differ depending on the activating stimulus. Interestingly, it was found that there were differences in the proliferative response of human bone marrow derived MSCs and human adipose tissue-derived MSCs to hPL or hPR (Bieback et al., 2009, 2010; Kinzebach et al., 2013; Kocaoemer et al., 2007; Schallmoser et al., 2007; Tchang et al., 2015).

In contrast to hPL, hPR, derived from physiological activation of platelets, has already undergone a clotting process, like serum in contrast to plasma. This obviates the need to add anticoagulants to the cell culture. The high calcium concentrations typically present in culture media overcome the anticoagulatory effects of citrate, therefore hPL require addition of, e.g., heparin to prevent gelling.

The mitogenic potential of thrombocytic growth factors was determined by specific stimulation of the ERK1/2 MAP kinase signaling cascade in quiescent renal epithelial LLC-PK $_{1}$ cultures (Rauch et al., 2011). Also, its effect on renal epithelial cell differentiation endpoints was compared to that of FBS. Monolayers of cultured renal epithelia grow as highly differentiated, polarized cells (Gstraunthaler, 1988). When cultured on permeable growth supports, cells form a transporting epithelium, separating an apical and a basolateral fluid compartment. In order to generate transepithelial transport in vitro, some requirements must be met by the culture system: retention of

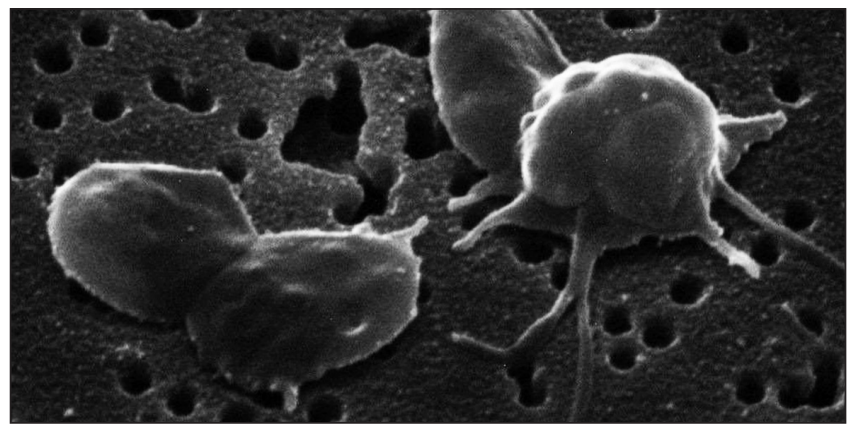

Fig. 1: Scanning electron micrograph of resting (left) and activated (right) human thrombocytes, immobilized on sterile filters

When platelets are activated, they undergo characteristic morphological changes and form long pseudopodia to adhere to the sites of vessel wall injury. In addition, thrombocytic granule factors, including vasoactive peptides, factors for initiating and maintaining the clotting cascade, and growth factors for subsequent wound healing, are released by exocytosis. Filters from Millipore Inc., pore size $0.22 \mu \mathrm{m}$. Micrograph taken by $\mathrm{G}$. Gstraunthaler.

the polar architecture and junctional assembly of the epithelial cells, presence of vectorial transport, sidedness of cellular uptake routes, and expression of kidney-specific metabolic and transport properties. The generation of transepithelial electrical resistance (TEER) can be determined as an overall parameter for the integrity of the cultured epithelium (Srinivasan et al., 2015). TEER was monitored in filter-grown LLC-PK 1 and in low- and high-resistance MDCK epithelia under FBS- or hPL-supplemented growth conditions. Low-resistance epithelia generated a TEER of $150-200 \Omega \mathrm{cm}^{2}$ in PL-supplemented media, as seen with FBS, and high-resistance MDCK I generated a TEER of $8,000 \Omega \mathrm{cm}^{2}$ under hPL as seen with FBS (Gstraunthaler et al., 2012), showing that FBS can be replaced by hPL without loss of differentiation potential.

Lucarelli et al. (2003) and Doucet et al. (2005) were the first to suggest using platelet-derived growth factors in the culture of human mesenchymal stromal cells. Mojica-Henshaw et al. compared hPL-serum converted from hPL plasma by recalcification with similar effects on growth of human MSC (Mojica-Henshaw et al., 2013). As different responses of MSCs and adipose-derived stem cells (ASCs) to hPL and hPR were observed, the proteomic profiles of both were compared, which was related at least in part with the biological function of the MSCs and ASCs (Kinzebach et al., 2013). Reduced fibrinogen concentration in hPR was also detected compared to hPL. This might be of therapeutic interest, as a recent study (Copland et al., 2013) observed that platelet lysate fibrinogen negatively affects the immunomodulatory capacity of MSC (up-regulation of indoleamine dioxygenase (IDO) and suppression of $\mathrm{T}$ cell proliferation).

Platelet (lysate) gels, the semisolid clot formed during platelet activation and fibrin formation, may become increasingly 
popular as scaffolds for reconstructive purposes, but also as 3D scaffolds for cell culture approaches (Fortunato et al., 2016; Walenda et al., 2012).

Also, platelet lysate of bovine whole blood has been successfully used as a general replacement for FBS in the culture of animal cell lines (Johansson et al., 2003).

\subsection{2 hPL in tissue storage and primary cell expansion for transplantation}

A cognate variant of expansion of stem cells is primary cell expansion as a part of patient treatment. Both stem cell cultures and primary cell expansion share the need for cell extraction from patient tissue. Both kinds of cells have to be cultured and expanded under very specialized conditions and one of the most important aspects is constancy in their cellular characteristics (Burnouf et al., 2016; Lee and Kay, 2006). After the in vitro treatment, both kinds of cells are intended to be re-transplanted into the patient to palliate symptoms or to cure an illness (Centeno et al., 2010; Parekh et al., 2016). The way from the donor/ patient tissue to in vitro cell culture and back to the patient has to be understood as a closed circle of patient related treatment. Bearing this in mind, the storage of human tissue is a still underestimated application where animal-free approaches could achieve benefits for the patient and the animals.

In corneal graft storage, for example, a highly regulated regime was installed to supervise and evaluate standards for the more than 40,000 operations performed in the United States and Europe alone every year. The North American Eye Bank Association recommends hypothermic storage and most eye banks use Optisol-GS. This medium is serum-free, thus metabolic activity in cold storage is very low. Nevertheless, the mean storage time of 2 days is very short and leads to a high rejection rate of the transplantation material. European eye banks use organ culture as a storage method for corneal grafts. This extends the mean storage time up to 24 days. The organ culture media contain 2 to $8 \%$ FBS (Doughman et al., 2012). A few approaches report the use of alternative media in organ or tissue storage, but none of these were brought to a new standard recommendation (Rieck et al., 2003; Smith and Johnson, 2012; Yokoo et al., 2008). In fact, all chemically-defined non-serum alternatives tested to date do not show a better endothelial cell survival under long-term storage conditions. The strict regulation of eye banks around the globe is an obstacle to the development of serum- or animal-free media for this application. An eye bank or a clinic switching their evaluated standard procedures risks their status as a supplier or transplantation center. Therefore, the interest in clinical studies investigating serum-free long-term storage conditions for transplantation grade corneal grafts is still very low considering the fact that the established norms work and that alternative approaches currently show no improvement over the FBS standard. Furthermore, the use of transplantation material for the evaluation of alternative media faces ethical concerns.

First approaches with corneal cell lines showed a higher vitality of cells grown with a processed variant of hPL (Thieme et al., 2016). Therefore, it is now unequivocally important to test hPL in corneal graft storage, since without clinical studies showing the superiority over the old FBS media there will be no update of the existing eye bank norms regarding animal-free storage media.

Only new organ bank recommendations demanding the use of serum-free media as first choice will lead to a stepwise replacement of animal serum in organ banking. The in vitro culture of primary cells or stem cells with animal free media would follow naturally from such cell banking conditions.

\subsection{3 hPL opportunities}

To summarize, platelet lysate appears to be a good and economical answer to the reproducibility and ethical issues related to the use of FBS. The source, animal whole blood from slaughterhouses or expired human donor thrombocytes from blood banks, is easily accessible. Both the availability and the ease of lysate preparation give hope that platelet lysate may replace FBS as universal growth supplement for highly specialized cell culture applications in the future, reviewed in Bieback (2013), Burnouf et al. (2016), Gstraunthaler et al. (2015), Hemeda et al. (2014), and Shih and Burnouf (2015). No figures are available

\section{Box 1: Commercial hPL products (companies)}

CLS Cell Lines Service (http://clsgmbh.de/p16287_human_Platelet_Lysate_(hPL).html)

COMPASS Biomedical

(http://www.compassbiomed.com/plus.html)

COOK Regentec

(http://stemulate.cookregentec.com/)

HELIOS BioScience

(http://www.atcbiomed.com/UltraGRO.html), distributed by

PL BioScience

(http://www.pl-bioscience.com/products/plsolution/)

macopharma

(http://platelet-lysate.macopharma.com/)

Mill Creek Life Sciences

(http://www.millcreekls.com/pltmax), distributed by MERCK MILLIPORE

PL BioScience (http://www.pl-bioscience.com/products/plsolution/)

STEMCELL Technologies

(https://www.stemcell.com/products/product-types/cell-culturemedia-and-supplements/human-platelet-lysate.html)

TRINOVA Biochem

(https://www.trinova.de/cruxrufa.php)

zenbio

(http://www.zen-bio.com/products/serum/fetal-bovine-serum. php)

Zentrum für Klinische Transfusionsmedizin Tübingen (http://www.blutspendezentrale.de/index.php?id=175) 
for annual amounts of expired donor platelets and manufacturing capacities but there are estimates that $50-60 \%$ of donor platelet units expire and have to be discarded. These could potentially be used for hPL production (Astori et al., 2016).

Efforts for standardization of hPL have recently been initiated. Since the number of reports on successful applications of hPL is steadily increasing, paralleled by an increase in the description of hPL preparation methods, there is clearly a need to reach international consensus on the production, quality, and safety criteria of hPL (Astori et al., 2016; Burnouf et al., 2016). So far, the promotion of cell proliferation, the differentiation behavior of stem cells, and the cellular metabolic activity, which are documented in many published studies, are commonly agreed parameters to prove the superiority of hPL over FBS.

With increasing acceptance of hPL as a valuable alternative to FBS, a market for hPL has evolved in recent years and hPL products have become commercially available. To date, 11 companies are known to manufacture or distribute hPL preparations (Box 1).

\subsection{Chemically-defined serum-free media}

Despite the disadvantages and critical ethical aspects discussed above, the global demand for FBS has increased continuously in the last decades. This phenomenon is not only driven by the growth of biotechnological and pharmaceutical industries, but is also associated with the current limitations of better defined media (van der Valk et al, 2010). Although increased selectivity for specific cell types or cell lines is one of the advantages of serum-free media, it also causes a decreased multiplicity in the use of the developed media. With an almost exponentially increasing number of newly identified or generated cell lines/ types every year (Freshney, 2005), more cell-specific media are needed. Non-specific media often lead to slower growth compared to FBS containing media (Chowdhury et al., 2012; Gottipamula et al., 2014). Furthermore, the substitution of serum with defined components requires not only extensive know-how and experience, but also a wide range of biochemical substances of high purity grade, the commercial availability of which is not always guaranteed or optimal.

One drawback for scientists moving away from FBS to chemically-defined serum-free media is the time and cost involved to identify a new FBS-free medium alternative for their specific cell types and to characterize cellular responses and "validate" their adaptation to the new environment. In other words: Are the cells proliferating and generally behaving differently in the presence of FBS-free formulations? And if so, does that mean "incorrectly" or just "differently" from their behavior in the presence of FBS? The key aspect of cellular systems in the absence of FBS is to aid scientists to emulate human in situ environments in a robust and reproducible manner.

Modifying the medium to specific cell requirements can be costly as FBS-free options can be more expensive than FBS. Ethically concerned funding organizations are often happy to provide additional financial support to cover these additional expenses. However, it is important to appreciate that implementing a slightly more expensive cell culture based system may not only address the ethical concerns of bovine fetal blood collection, but also may result in a cell based system that performs better (e.g., better reproducibility) and is able to better reflect the in situ human microenvironment.

Also, the increasing interest in primary cell culture is driving a shift in cell culture media preferences, with more scientists purchasing more chemically-defined media (DePalma, 2016). The increasing demand for such media may promote a reduction of costs over time. It should also be noted that the costs associated with the use of FBS can be even higher, as FBS accounts for up to $85 \%$ of the overall cost of the medium, especially when calculated for large-scale cultures (Ozturk and $\mathrm{Hu}, 2005)$.

A commercial manufacturer is able to optimize the cost efficiency of chemically-defined serum-free media not only with product specific know-how, but also by economically effective managed production. In the past decades, the reliable commercial supply of defined media and the standardization introduced by the bio-pharma industry have played important roles in the development of the animal cell culture technology and the use of serum-free media. Due to increasing regulatory pressure to eliminate animal components in cell culture products and biopharmaceuticals (EMA, 2013; ESAC, 2008; USP, 2012), increased demand for serum-free cell culture media has been observed. By 2022, a total value of 11.3 billion US dollars of the global cell culture market is estimated, with a cumulative annual growth rate (CAGR) of $7.1 \%$. The cell culture media segment will have a leading share in the global market with the highest CAGR of $8.8 \%$ (Anon., 2015).

However, the commercialization of serum-free media is not without disadvantages. The exact formulations of many commercially available serum-free media are often a corporate secret. Alternative concepts, including hPL as alternative FBS substitutes, serum-free databases, and alternative cell culture concepts/systems need to be developed and existing platforms to be extended to allow more widespread use of serum-free media also in countries where resources are limited.

Medium 199 (Morgan et al., 1950) and Ham's Nutrient Mixture F-10 and F-12 (Ham, 1963, 1965) were the first culture media specifically designed for use without serum supplementation. Medium 199, in addition to the base components of electrolytes, amino acids and glucose, is highly enriched with vitamins and trace elements suitable for the serum-free culture of chicken embryo fibroblasts. Ham's F-12 medium additionally contains zinc sulfate, putrescine, and linoleic acid. $\mathrm{CHO}$ cells can be grown in this medium without serum supplementation. Ham's F-12 in a 50:50 (v/v) mixture with Dulbecco's modified MEM (DMEM), is the basal medium for chemically-defined serum-free cell culture (Barnes and Sato, 1980a,b). This basal medium is supplemented with cell-specific hormones, growth factors, and trace elements. The addition of insulin, transferrin, and selenium (ITS) is also required (Gstraunthaler, 2003; Jayme, 1999). Details are outlined in the report of the $2^{\text {nd }}$ workshop (van der Valk et al., 2010), where a media pyramid was designed to inform on how to build a chemically-defined serum-free medium. 


\subsubsection{Development of new cell lines in serum-free medium only}

The rapidly growing field of stem cell research, human embryonic stem cells (hESCs) and human induced pluripotent stem cells (hiPSCs), in particular, holds great promise for regenerative medicine, toxicology and biomedical research. Both $\mathrm{hESCs}$ and hiPSCs are generally maintained on inactivated mouse or human embryonic fibroblasts (feeder cells) or under feeder-free conditions (on extracellular matrices) in media supplemented with proprietary replacements as alternatives to FBS, in an effort to better control the phenotype of the cells (i.e., stem-ness maintenance, pluripotency, and differentiation towards a desired cell lineage). Indeed, given the presence of undefined or unknown components in FBS, serum-free culture systems now have been optimized to avoid the possible effects elicited by undefined differentiating growth factors and the risk of contaminations from pathogens potentially present in animal sera (e.g., mycoplasma, viruses, and prions) (Pistollato et al., 2012; Yamasaki et al., 2014).

These aspects were discussed in the first GCCP guideline, which dates back to 2005 (Coecke et al., 2005). A recently published document expands these aspects, specifically addressing which standards and quality controls should be considered for the culture of stem cell-derived models (Pamies et al., 2017). This publication, which represents a first step towards a revised GCCP 2.0, comments on the need to preferentially apply serum-free media, (animal) protein-free media and chemically-defined media to avoid many disadvantages associated with the use of serum (Pamies et al., 2017). In this regard, as serum may induce spontaneous differentiation of iPSCs, fully chemically-defined media, supplemented with appropriate hormones and growth factors (van der Valk et al., 2004, 2010), may be used. Serum-free media are thought to circumvent the batchto-batch variability issues associated with serum and increase reproducibility and the differentiation efficiency of stem cells towards specific cell derivatives (Geraghty et al., 2014). Clearly, the use of alternatives to FBS has particular relevance when stem cells are intended to be applied for replacement therapies to avoid serum-related biosafety concerns (i.e., xenoimmunization and the risk of disease transmission by pathogens) (Mannello and Tonti, 2007; Rakian et al., 2015; Schallmoser et al., 2008; Shahdadfar et al., 2005; Tonti and Mannello, 2008).

However, it should be noted that serum-free compositions may still require validation and monitoring similar to serum-containing media. Particularly, serum-free media can also contain poorly defined supplements (e.g., pituitary extracts, chick embryo extracts, bovine milk fractions, bovine colostrum or platelet lysates (van der Valk et al, 2010)). For instance, B27 and the analogous NS21, which are commonly used supplements for the culture of neural cells, contain bovine serum albumin and transferrin, which can exhibit different batch-to-batch biological activity (Chen et al., 2008). Also, the so-called "basement membrane extract" (BME), purified from Engelbreth-Holm-Swarm murine sarcoma cells and marketed under different names (e.g., BME, Matrigel, and Cultrex) is prone to batch-to-batch variability. Additionally, while some supplement formulations are defined (e.g., Insulin-Transferrin-Selenium (ITS) supplement from Thermo Fisher), others are proprietary mixtures and, as a consequence, undefined, and for this reason different batches should be tested as for serum (Geraghty et al., 2014).

Likewise, other so-called "defined" media still contain complex plasma proteins. The widely used $\mathrm{mTeSR}^{\mathrm{TM}} 1$ medium (STEMCELL Technologies Inc.) for serum-free culture of human embryonic (hESC) and induced pluripotent (hiPSC) stem cells is supplemented with human serum albumin, human holo-transferrin and human insulin (Ludwig et al., 2006). Optimization of $\mathrm{mTeSR}^{\mathrm{TM}} 1$ led to the development of chemically-defined albumin-free E8 medium (Chen et al., 2011).

A novel serum substitute, named XenoFree Serum Substitute (XFS2), specifically tailored to the needs of human cell culture, was recently introduced by Celprogen. XFS2 was reported to support the culture of stem cells, progenitor cells, iPSCs, primary human cells, but also cancer stem cells, circulating tumor cells, and differentiated parental tumor cells. Interestingly, this serum replacement is completely composed of synthetic ingredients, supporting the culture of human cells under chemically-defined conditions (DePalma, 2016).

\subsubsection{Case studies of chemically- defined serum-free applications}

For several cell types, serum-free media have been described and are now also commercially available, see for instance: "Serum-free media for cell culture" compiled by the Animal Free Research UK (Animal Free Research UK, 2014). Below, selected examples of serum-free applications are reported.

\subsubsection{Serum-free application of cell line $\mathbf{L} \mathbf{9 2 9}$}

The mouse fibroblast cell line L929 was adapted to serum-free DME/F12+ITS medium (van der Valk et al., 2010). Before the adaptation, the cells were cultivated in standard cell culture flasks, fresh DMEM $+10 \%$ FBS medium was applied after 3 days and cells were split after 7 days. For the adaptation, 100,000 cells were transferred to a $25 \mathrm{~cm}^{2}$ Greiner Bio One Cellstar advanced (Frickenhausen/Germany) flask with $4 \mathrm{ml}$ serum-free medium and the culture routine was continued. The doubling time of the cells increased from around $18 \mathrm{~h}$ to $25 \mathrm{~h}$. However, the serum-free cells proliferated over months and were available for experiments continuously during this time.

\subsubsection{A test for eye irritation following the Cytosensor Microphysiometer (CM) Toxicity Test - INVITTOX $n^{\circ} 130$}

To conduct tests for eye irritation of new chemicals, the IMOLA-IVD technology (Eggert et al., 2015) was adapted to perform similar experiments to the validated cytosensor microphysiometer test (INVITTOX no. 1302; Weiss et al., 2013). The

2 INVITTOX no. 130. https://eurl-ecvam.jrc.ec.europa.eu/validation-regulatory-acceptance/topical-toxicity/eye-irritation/ (accessed 02.21.2017). 


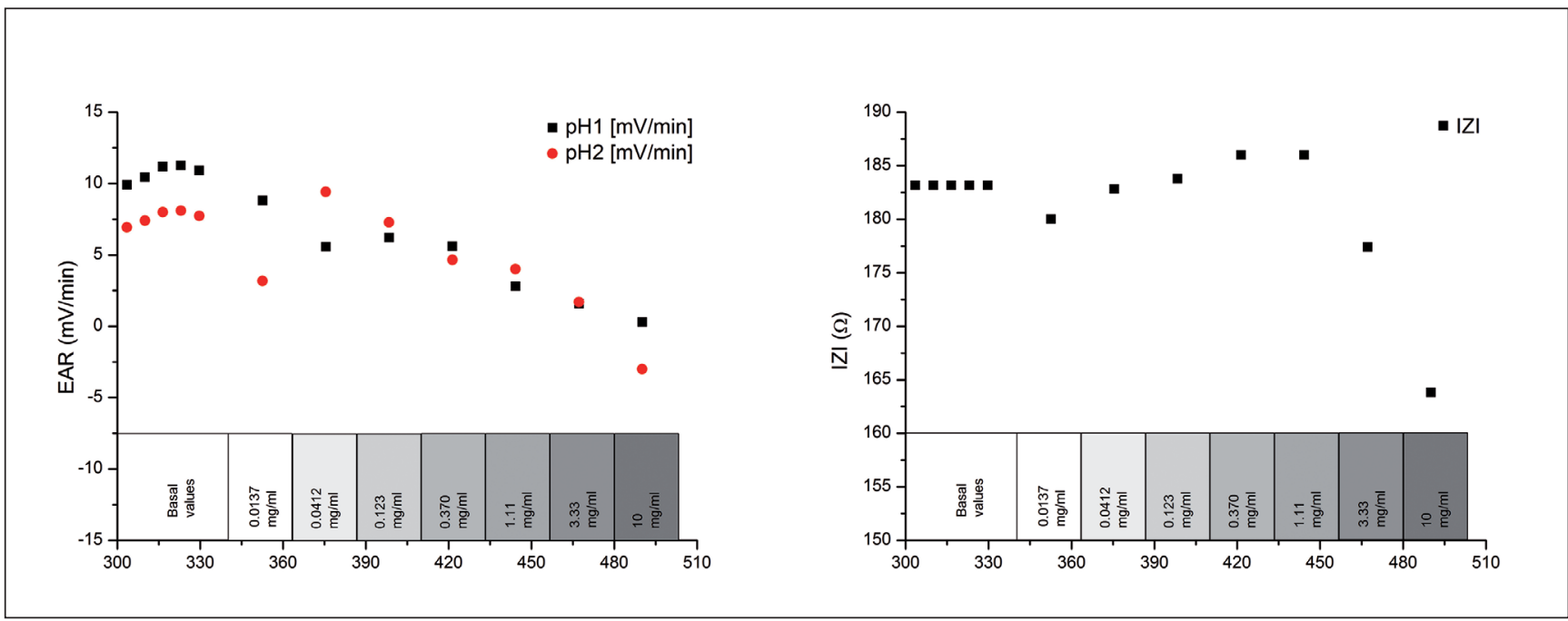

Fig. 2: Test for the eye irritation potential of seven dilutions of sodium dodecyl sulfate toward L929 fibroblasts

Left: extracellular acidification rate (EAR), right: modulus of impedance (IZI). The first five recordings of the basal rates are shown, followed by seven dilutions of sodium dodecyl sulfate.

IMOLA-IVD is a fully automated, label-free, microphysiological system mounted in an incubator to perform measurements at $37^{\circ} \mathrm{C}$. The standard set-up consists of 6 IMOLA systems using BioChips with living cells. Six fluidic modules with valves and air bubble detectors allow pre-programmed switching between flasks with cell culture media and the substance under investigation. A computer-controlled multi-channel pump drives the media to and from the BioChips. The BioChips are equipped with micro-sensors for $\mathrm{pH}$, dissolved oxygen and impedance. Thus, it is possible to monitor extracellular acidification, cellular respiration and changes in morphology of living cells. In the presented experiment, the system was programmed to supply L929 mouse fibroblast cells for $330 \mathrm{~min}$ with pure cell culture media. Then seven dilutions of sodium dodecyl sulfate (SDS) were subsequently pumped to the cells, starting with the highest dilution. During the experiment, the effect of seven dilutions of SDS on extracellular acidification and impedance toward L929 cells was recorded. In a further development, the serum-free L929 cell line was used and the tests were performed with serum-free DME/F12+ITS medium (Wiest, 2017). Figure 2 shows the results of the chemically-defined experiments. The first five recordings of the basal rates are shown, followed by seven dilutions of SDS. For better readability, the presented data was pre-processed using a script based algorithm to extract acidification rates and modulus of impedance (Wiest et al., 2016) from the raw data.

The results show that eye irritation can be tested with L929 cells cultivated in serum-free medium.

4.2.5 A test for cytotoxicity following ISO 10993-5 Tests for biocompatibility/cytotoxicity of new materials are needed for biological evaluation of medical devices as described in ISO 10993-5 (ISO, 2017). Besides extract tests and indirect contact tests, a direct contact test is specified, which requires the incubation of mammalian cells in contact with a device. The norm specifies, among others, positive, negative and a blank control, a minimum of three replicates, sterility and the use of established cell lines. For the test, the serum-free L929 cell line was used and silicone or aluminum were used as negative controls. For the positive controls, PATTEX Multi or a copper band is recommended. For validation, a number of experiments were performed in parallel with L929 cultured in DMEM $+10 \%$ FBS. The serum-free tests delivered the same results as the FBS based tests.

In conclusion, cytotoxicity testing according to ISO 10993-5 is possible with L929 fibroblasts in chemically-defined cell culture medium (Wiest, 2016).

\subsubsection{Organ system}

A 4-organ system has been developed consisting of liver, cardiac, neuronal and muscle tissues in a serum-free, circulating medium over 14 days that was used to determine multi-organ toxicity for 5 common drugs (Oleaga et al., 2016). This was accomplished utilizing a pumpless platform as shown in Figure 3.

Computer simulations of the platform utilizing a commercially available computational fluid dynamics package (CFD$\mathrm{ACE}+$ ) established flow rates and resultant shear stress within physiological ranges. Viability of the system for 14 days was demonstrated with functional activity of the human cardiac, muscle, neuronal and liver modules. The integrated modules were evaluated for their response to 5 drugs 7 days after a 48-hour treatment regime. System evaluations were based on cellular viability, production of urea and albumin, electrophysiological responses, and cardiomyocyte and muscle contraction frequency. The drugs doxorubicin, atorvastatin, valproic acid, acetaminophen and $\mathrm{N}$-acetyl-m-aminophenol 
a

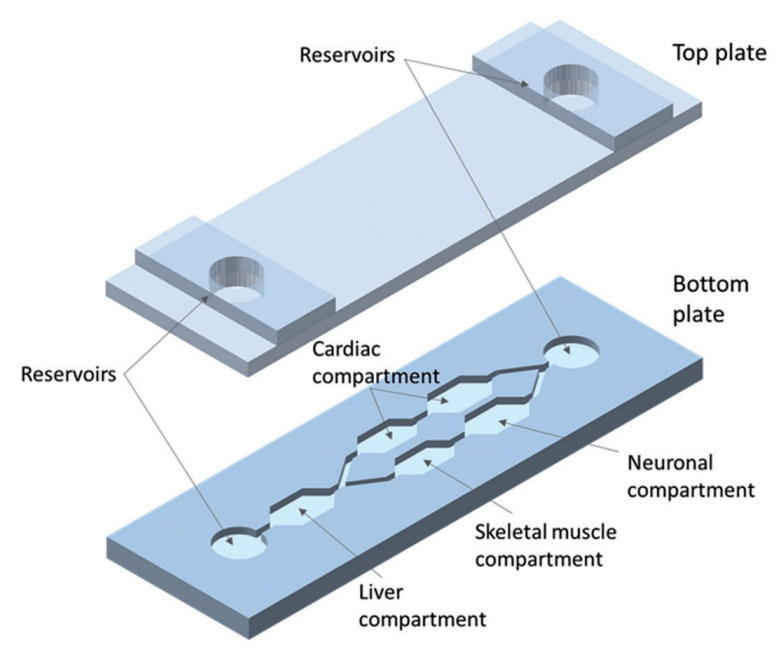

b

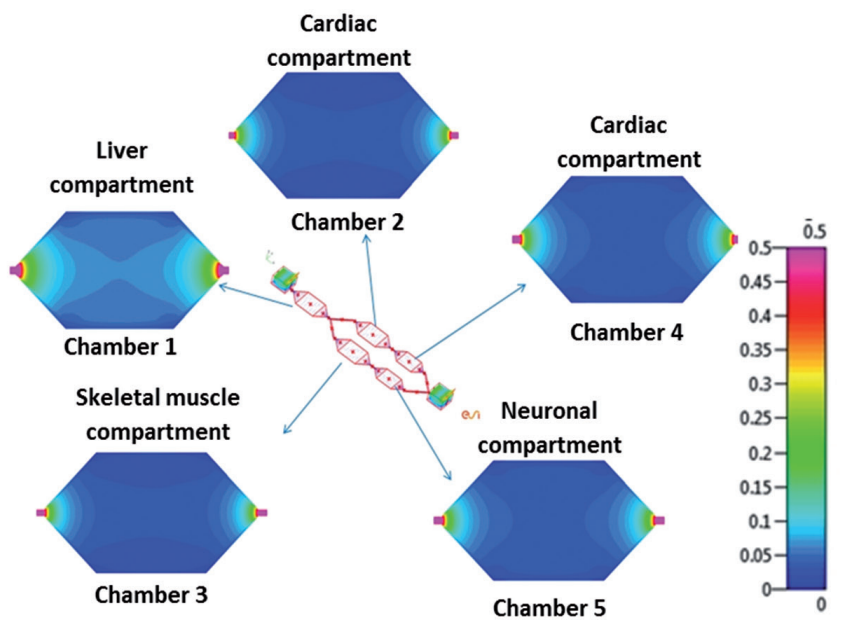

(dynes $/ \mathrm{cm}^{2}$ )

Fig. 3: Schematic view of a 4-organ microfluidic platform

(a) Schematic view of the microfluidic platform showing the different cell compartments of a 4-organ system. The system contained two holders for the separate culture devices. Total fluid volume was approximately $4 \mathrm{ml}$ between the chambers and reservoirs.

The sizes of the culture compartments were $35.8 \times 18.4 \times 0.3 \mathrm{~mm}$ for Chambers $1,2,3$ and $29.8 \times 15.4 \times 0.7 \mathrm{~mm}$ for Chambers 4 and 5 . The connecting channel dimensions were $5.7 \times 1 \times 0.3 \mathrm{~mm}$. (b) Shear stress distribution in each compartment of the system. Reproduced with permission from Oleaga et al. (2016).

were tested and the results correlated well with toxicological effects reported in the literature (Oleaga et al., 2016). This low-cost platform is self-contained and allows for continuous serum-free medium circulation with periodic medium supplementation and analyte analysis. The operating time has been extended to 28 days with daily removal of $30 \%$ of the reservoir volume for analysis and replacement with fresh medium. This system is the first microfluidic model to demonstrate the capacity to promote the survival and functional competence of 4 interconnected tissue modules in serum-free medium over extended culture periods. The prototype model used human cells: (a) for the cardiac compartment induced pluripotent stem cells (iPSC) differentiated into cardiomyocytes (from Cellular Dynamics International, CDI) were applied; (b) for the skeletal muscle, compartment skeletal myofibers were prepared by isolation and differentiation steps described in Guo et al. (2014); (c) for the neuronal system, motoneurons were differentiated (Guo et al., 2011) from a previously isolated human spinal cord stem cell (hSCSC) line; and (d) for the liver compartment, a cell line from a hepatocellular carcinoma HepG2/C3A (ATCC ${ }^{\circledR}$ CRL-10741) was used in the prototype system. The serum-free medium is based on that described by Guo et al. (2011) except for the addition of an antibiotic/ antimycotic cocktail and the elimination of the G5 supplement.
This system demonstrated that complex human in vitro systems can be constructed using a common serum-free medium without FBS.

\section{Serum-free databases}

As discussed in the preceding text, a broad array of serum-free culture media has been published in the past decades. Unfortunately, serum-free medium formulations have in most part been confined to specific cell types or cell lines, but their application is now being extended to a broader list of cell types. However, the search for cell-specific serum-free media can be time-consuming and tedious work requiring either a broad literature survey or a search for commercially available serum-free media (Brunner et al., 2010).

A solution to this issue is the development of freely accessible serum-free media databases with comprehensive search functions. These databases should be regularly updated and their existence promoted. This approach also addresses the continued issue of "raising awareness", is cost effective and a relatively simple activity to significantly and meaningfully help to reduce or even completely replace FBS in cell culture medium wherever possible. 
A decade ago, Focus on Alternatives (FoA), a group of charities and organizations ${ }^{3}$, collaborated to produce an excellent and impactful resource to further increase the awareness of commercially available animal-sera free cell culture media. Animal Free Research UK (AFR), decided to independently continue to support and develop this important database for the wider scientific community under the name FCS-free database ${ }^{4}$.

Currently available FBS-free media databases, including the one hosted and curated by AFR, are limited in that they typically only promote commercially available alternatives and do not contain details of media described in the scientific literature but not sold commercially. Serum-free media are already commercially available for many cell types, but are generally cell type specific (Tan et al., 2015). Additionally, for some cell types there are a number of viable options, however, there is a limitation in that the different options can elucidate different cellular responses (Rodrigues et al., 2012). Although these media are widely regarded as chemically-defined, the formulations of such alternative solutions are seldom released, which the authors assume is for proprietary reasons. As a general rule, limited information is usually communicated (e.g., whether the medium contains animal-derived components or not). In some situations, knowledge of the precise formulation of the medium may assist in developing a robust and critical interpretation of experimental results. This information may also provide opportunities to improve the medium to obtain the expected (in situ) properties of the cell.

It is therefore important that any future database does not ignore the FBS-free media solutions described in the literature. However, to date, this information has not been collated. To facilitate the identification of existing serum-free media for a specific cell type, and to provide the digital infrastructure for scientists to share experiences as well as best practice and media improvements, it is recommended that any future database on FBS alternatives also includes published serum-free media formulations.

Any such database should incorporate a number of key features, i.e., it should be:

- Free to use

- Searchable under numerous different fields

- Hosted through reliable and well respected digital avenues (ideally with duplicate sites)

- Continually curated and updated (and dated to demonstrate this)

- Populated, not only with commercially available options but also including successful, peer-reviewed published solutions and their methods.
- Well publicized through appropriate sources for maximum impact throughout the scientific community (e.g., conferences, webinars, social media - particularly LinkedIn-dedicated groups, intranet channels, organizations' newsletters and through targeted advertising campaigns in scientific journals and 3Rs focused websites).

To achieve these outcomes, it is vitally important to establish secure and sustainable funding sources.

\section{Conclusions and recommendations}

From an animal welfare point of view, the current practice of obtaining FBS is unacceptable because of the potential suffering the fetuses might experience during the entire process. A compulsory rule requiring the stunning or killing of fetal calves before blood collection should be implemented immediately to reduce the suffering of unborn calves for scientific and commercial activities.

Harvesting of FBS from living fetuses in Europe has to be considered a procedure under the Directive 2010/63/EU and therefore, if not banned, should at least undergo the proper peer review and authorization process. There is a need for better legal protection of all fetal forms of vertebrates as we cannot exclude suffering before birth. Generally, authorities, at least within the EU and other countries that legally protect fetuses under their animal experimentation legislation, will have to find ways to assure that all provisions also are fully applied to FBS production, most prominently a cost-benefit analysis and rigid application of all 3Rs. If this cannot be implemented, the final consequence would be that licensing of FBS production is stopped as alternatives are developed and equivalence is demonstrated (ESAC, 2008).

The scientific community should go one step further and also question the frequent and routine use of FBS in scientific projects from a moral perspective. Even without - at present - proper legal handling of the issue, it seems evident that there is a moral obligation to apply the 3 Rs principle to the use of FBS. The obligation to use alternative methods wherever possible is very clear and it is therefore difficult to understand that the 3Rs continue to be ignored in this matter, as scientists around the world appear to be hesitant to switch to using serum-free media for their experiments. Anyhow, the use of FBS, when collected in a way that causes suffering, seems at odds with, and morally problematic in the context of, application or development of in vitro methods that are meant to replace and reduce animal use ${ }^{5}$. Therefore, scientists who develop 3Rs methods especially should promote serum-free methods, independent of legal pressure.

\footnotetext{
3 Dr Hadwen Trust (now: Animal Free Research UK), FRAME, The Humane Research Trust, RSPCA, Advocates for Animals, UK Human Tissue Bank and the Lord Dowding Fund.

4 The database is available online (https://fcs-free.org/) as part of the 3Rs Database program of the 3Rs-Centre Utrecht Life Sciences.

5 Article 4

Principle of replacement, reduction and refinement

1. Member States shall ensure that, wherever possible, a scientifically satisfactory method or testing strategy, not entailing the use of live animals, shall be used instead of a procedure."
}

(Dir. 2010/63/EU) 
Tab. 2: List of recommendations to ease and support the transition toward serum-free culture conditions

\begin{tabular}{|c|c|c|}
\hline \multicolumn{2}{|c|}{ Recommendations } & \multirow{2}{*}{$\begin{array}{l}\text { Comments } \\
\text { The use of FBS currently represents a potential legal } \\
\text { issue (as per the Directive No 2010/63/EU); also, at } \\
\text { initial production and marketing stages, chemically- } \\
\text { defined media can be expensive. }\end{array}$} \\
\hline R1 & $\begin{array}{l}\text { Funding for the production and marketing of serum-free } \\
\text { culture models should be generally supported and } \\
\text { implemented in Europe and worldwide. }\end{array}$ & \\
\hline $\mathbf{R} 2$ & $\begin{array}{l}\text { Funding should be allotted for research proposals } \\
\text { aiming at developing cocktails of defined growth factors, } \\
\text { hormones etc., suitable to support in vitro cell growth, } \\
\text { proliferation, differentiation and terminal maturation of } \\
\text { different cell types, followed by formal validation of serum- } \\
\text { free culture models. }\end{array}$ & $\begin{array}{l}\text { National funding programs should require that any } \\
\text { institution supporting } 3 \mathrm{R} \text { methods should prioritize for } \\
\text { funding grant proposals based on serum-free methods/ } \\
\text { models; funding bodies should give the proponents } \\
\text { enough time to work on the shift to serum-free } \\
\text { conditions, when intentioned to do so. }\end{array}$ \\
\hline R3 & $\begin{array}{l}\text { There should not be the need to keep referring to FBS- } \\
\text { based protocols, provided that a new serum-free method } \\
\text { is available and equally comparable. }\end{array}$ & $\begin{array}{l}\text { This may encourage scientists to switch to serum-free } \\
\text { approaches, avoiding the concern of losing previously } \\
\text { generated data. }\end{array}$ \\
\hline R4 & $\begin{array}{l}\text { Commercially available serum-free supplements should } \\
\text { be standardized and rigorously validated for various types } \\
\text { of cell cultures. }\end{array}$ & $\begin{array}{l}\text { This would help circumvent batch-to-batch variability, } \\
\text { as it commonly happens with FBS. }\end{array}$ \\
\hline R5 & $\begin{array}{l}\text { Cell suppliers, such as stem cell banks, should make } \\
\text { specific requirements in culture method descriptions, } \\
\text { addressing the need to apply FBS-free media (if such } \\
\text { exists), particularly for the culture of (pluripotent) stem } \\
\text { cells. }\end{array}$ & $\begin{array}{l}\text { Cell banks should prioritize cell culture methods } \\
\text { that apply serum-free protocols to better control cell } \\
\text { phenotype, and make more efforts to advertise cell } \\
\text { cultures that do not require the use of FBS. }\end{array}$ \\
\hline $\mathbf{R 6}$ & $\begin{array}{l}\text { Serum-free databases, with comprehensive search } \\
\text { functions and free access, should be implemented. }\end{array}$ & $\begin{array}{l}\text { These represent important tools to support researchers } \\
\text { with information on the selection of appropriate serum- } \\
\text { free media; commercial records should be expanded } \\
\text { with newly published information. }\end{array}$ \\
\hline R7 & $\begin{array}{l}\text { Educational and outreach activities should be organized } \\
\text { to inform researchers on the ethical and scientific } \\
\text { limitations of FBS, current regulations, and commercially } \\
\text { available serum-free media. }\end{array}$ & $\begin{array}{l}\text { These activities may be organized in academic } \\
\text { institutions and by using webinars, lectures, Linkedln } \\
\text { groups and intranet channels. }\end{array}$ \\
\hline $\mathbf{R 8}$ & $\begin{array}{l}\text { A legal framework and guidance for authorities' licensing } \\
\text { procedures under Directive 2010/63/EU is needed for } \\
\text { the production of FBS if carried out on EU territory }\end{array}$ & $\begin{array}{l}\text { Report could be sent to DG ENV and this specific } \\
\text { issue mentioned in the cover letter. }\end{array}$ \\
\hline
\end{tabular}

In addition to the ethical and legal aspects, there are several scientific arguments against the use of FBS. There is thus a clear need for the replacement of FBS and for the design of serum-free cell culture media, respectively, which will result in better standardization and data reproducibility of in vitro applications (Gstraunthaler et al., 2014) and will substantially contribute to GCCP (Coecke et al., 2005). Due to the large commercial interest in providing FBS, fraudulent practices have become apparent, which will have an effect on, among other issues, reproducibility, adding to the reproducibility crisis (Baker, 2016a). The use of FBS in Biological Resource Centers is also becoming problematic since changes in the phenotype and genotype of cell lines when changing to new FBS batches might not always be obvious.

Although FBS is a powerful universal supplement for cell culture, from a scientific point of view FBS is not suitable for the following applications:

- To study the functional or regulatory effects of exosomes, growth factors or hormones due to the contamination caused by serum (Dietrich et al., 2011; Rauschenberger et al., 2016); - To induce the differentiation of stem cells in a controlled or reproducible manner (Puts et al., 2016);

- To perform co-culture tests with fibroblasts (Harati et al., 2016; Nikolakis et al., 2015).

Furthermore, it is highly recommended to replace FBS with chemically-defined components, particularly in in vitro toxicity tests, to improve the sensitivity and reproducibility (Hahne and Reichl, 2011; Peter et al., 2007), since serum-free formulations may still contain poorly defined supplements.

Unfortunately, no universal chemically-defined medium is yet available, meaning that a suitable chemically-defined medium has to be developed for every existing cell line. To facilitate the identification of existing serum free media, it is recommended that a freely available database, providing information both on commercially available formulations as well as those described in literature, is established. 
Although the workshop and its conclusions focused mainly on the use of FBS in research, the same issues apply also in the area of cellular therapies (Karnieli et al., 2017) and in vitro meat production (Post, 2012).

However, despite the severe ethical and scientific concerns, a stop to the use of FBS in cell cultivation cannot be realized without offering real technical alternatives. Many of the commercially available chemically-defined FBS replacements or serum-free media still need improvement with regard to the performance and the cost, compared to FBS. To effectively reduce the use of FBS, hPL can be considered a good alternative to serum, however, with limited potential to develop fully defined media. Alternatively, serum replacements can be used to significantly reduce the amount of FBS in the cell culture medium. For most of the commonly used cell lines, cultivation of the cells only becomes challenging if the final concentration of FBS is lower than $1 \%$ (in combination with additional chemically-defined serum-free replacements). At this low concentration, the culture medium has become notably defined, while the reproducibility of the experiments can be improved significantly (Schlingensiepen et al., 2011). However, the examples presented here demonstrate that it is possible to obtain reliable results in serum-free cell and complex organ systems. Furthermore, when establishing new cell lines, it is recommended to start from the beginning with serum-free, preferably chemically-defined, media.

For all these reasons, serious effort should be made in the short term to support the production and marketing of both traditional and more recently generated cell cultures, all under serum-free conditions, and to encourage the scientific community to use them. Fortunately, guidelines such as the Good Cell Culture Practices discourage the use of FBS (Coecke et al., 2005; Pamies et al., 2017). In addition, because of contamination issues, the use of FBS during the production of biologicals is discouraged (EMA, 2013; USP, 2012).

In line with this, we propose a list of recommendations with the aim to ease and support this transition process (Tab. 2).

\section{References}

Almeida, J. L., Cole, K. D. and Plant, A. L. (2016). Standards for cell line authentication and beyond. PLoS Biol 14, e1002476. doi:10.1371/journal.pbio.1002476

Animal Free Research UK (2014). Serum-free media for cell culture. https://www.animalfreeresearchuk.org/serum-freemedia (accessed 08.01.2017).

Anon. (2015). Cell culture media, sera, and reagents market - Global industry analysis, size, share, growth, trends, and forecast 2015-2023. http://www.transparencymarketresearch. com/cell-culture-media-sera-reagents-market.html (accessed 02.21.2017).

Astori, G., Amati, E., Bambi, F. et al. (2016). Platelet lysate as a substitute for animal serum for the ex-vivo expansion of mesenchymal stem/stromal cells: Present and future. Stem Cell Res Ther 7, 93. doi:10.1186/s13287-016-0352-x

Baker, M. (2016a). Is there a reproducibility crisis? Nature 533,
452-454. doi:10.1038/533452a

Baker, M. (2016b). Reproducibility: Respect your cells! Nature 537, 433-435. doi:10.1038/537433a

Balk, S. D., Levine, S. P., Young, L. L. et al. (1981). Mitogenic factors present in serum but not in plasma. Proc Natl Acad Sci U $S$ A 78, 5656-5660. doi:10.1073/pnas.78.9.5656

Balls, M., Goldberg, A. M., Fentem, J. H. et al. (1995). The three Rs: The way forward. The report and recommendations of ECVAM Workshop 11. Altern Lab Anim 23, 838.

Barallon, R., Bauer, S. R., Butler, J. et al. (2010). Recommendation of short tandem repeat profiling for authenticating human cell lines, stem cells, and tissues. In Vitro Cell Dev Biol Anim 46, 727-732. doi:10.1007/s11626-010-9333-z

Barnes, D. and Sato, G. (1980a). Methods for growth of cultured cells in serum-free medium. Anal Biochem 102, 255-70. doi:10.1016/0003-2697(80)90151-7

Barnes, D. and Sato, G. (1980b). Serum-free cell culture: A unifying approach. Cell 22, 649-655. doi:10.1016/00928674(80)90540-1

Barnes, D., McKeehan, W. L. and Sato, G. H. (1987). Cellular endocrinology: Integrated physiology in vitro. In Vitro Cell Dev Biol 23, 659-662. doi:10.1007/BF02620978

Bieback, K., Hecker, A., Kocaömer, A. et al. (2009). Human alternatives to fetal bovine serum for the expansion of mesenchymal stromal cells from bone marrow. Stem Cells 27, 2331-2341. doi:10.1002/stem. 139

Bieback, K., Ha, V. A., Hecker, A. et al. (2010). Altered gene expression in human adipose stem cells cultured with fetal bovine serum compared to human supplements. Tissue Eng Part A 16, 3467-3484. doi:10.1089/ten.tea.2009.0727

Bieback, K. (2013). Platelet lysate as replacement for fetal bovine serum in mesenchymal stromal cell cultures. Transfus Med Hemoth 40, 326-335. doi:10.1159/000354061

Bilgen, B., Orsini, E., Aaron, R. K. and Ciombor, D. M. (2007). FBS suppresses TGF- $\beta 1$-induced chondrogenesis in synoviocyte pellet cultures while dexamethasone and dynamic stimuli are beneficial. J Tissue Eng Regen Med 1, 436-442. doi:10.1002/term.56

Biowest (2016). Fetal bovine serum. Technical datasheet. http://www.biowest.net/media/s1800t 0967581001125 31082016.pdf (accessed 02.21.2017).

Bjare, U. (1992). Serum-free cell culture. Pharmacol Ther 53, 355-374. doi:10.1016/0163-7258(92)90056-6

Blair, P. and Flaumenhaft, R. (2009). Platelet $\alpha$-granules: Basic biology and clinical correlates. Blood Rev 23, 177-189. doi:10.1016/j.blre.2009.04.001

Brindley, D. A., Davie, N. L., Culme-Seymour, E. J. et al. (2012). Peak serum: Implications of serum supply for cell therapy manufacturing. Regen Med 7, 7-13. doi:10.2217/rme.11.112

Brunner, D., Frank, J., Appl, H. et al. (2010). Serum-free cell culture: The serum-free media interactive online database. ALTEX 27, 53-62. doi:10.14573/altex.2010.1.53

Burnouf, T., Goubran, H. A., Chen, T. et al. (2013). Blood-derived biomaterials and platelet growth factors in regenerative medicine. Blood Rev 27, 77-89. doi:10.1016/j. blre.2013.02.001 
Burnouf, T., Strunk, D., Koh, M. B. and Schallmoser, K. (2016). Human platelet lysate: Replacing fetal bovine serum as a gold standard for human cell propagation? Biomaterials 76, 371387. doi:10.1016/j.biomaterials.2015.10.065

Busher, J. T. (1990). Serum albumin and globulin. In H. K. Walker, W. D. Hall and J. W. Hurst (eds.), Clinical Methods: The History, Physical, and Laboratory Examinations (497499). $3^{\text {rd }}$ edition. Boston, USA: Butterworths.

Capes-Davis, A. and Neve, R. M. (2016). Authentication: A standard problem or a problem of standards? PLoS Biol 14, e1002477. doi:10.1371/journal.pbio.1002477

Castiglia, S., Mareschi, K., Labanca, L. et al. (2014). Inactivated human platelet lysate with psoralen: A new perspective for mesenchymal stromal cell production in good manufacturing practice conditions. Cytotherapy 16, 750-763. doi:10.1016/j. jcyt.2013.12.008

CellSystems (2012). Standard operating procedure - In vitro skin corrosion: Human skin model test epiCS ${ }^{\circledR}$ CellSystems. Version 4.3. http://cellsystems.de/files/epiCS/SOP-epiCS-skin-corrosion.pdf (accessed 02.20.2017).

Centeno, C. J., Schultz, J. R., Cheever, M. et al. (2010). Safety and complications reporting on the re-implantation of culture-expanded mesenchymal stem cells using autologous platelet lysate technique. Cur Stem Cell Res Ther 5, 81-93. doi:10.2174/157488810790442796

Chen, G., Gulbranson, D. R., Hou, Z. et al. (2011). Chemically defined conditions for human iPSC derivation and culture. Nat Methods 8, 424-429. doi:10.1038/nmeth.1593

Chen, Y., Stevens, B., Chang, J. et al. (2008). NS21: Re-defined and modified supplement B27 for neuronal cultures. $J$ Neurosci Methods 171, 239-247. doi:10.1016/j.jneumeth.2008.03.013

Choi, Y. C., Morris, G. M. and Sokoloff, L. (1980). Effect of platelet lysate on growth and sulfated glycosaminoglycan synthesis in articular chondrocyte cultures. Arthritis Rheum 23, 220-224. doi:10.1002/art.1780230213

Chowdhury, S. R., Aminuddin, B. and Ruszymah, B. (2012). Effect of supplementation of dermal fibroblasts conditioned medium on expansion of keratinocytes through enhancing attachment. Indian J Exp Biol 50, 332-339.

Coecke, S., Balls, M., Bowe, G. et al. (2005). Guidance on good cell culture practice. A report of the second ECVAM task force on good cell culture practice. Altern Lab Anim 33, 261-287.

Copland, I. B., Garcia, M. A., Waller, E. K. et al. (2013). The effect of platelet lysate fibrinogen on the functionality of MSCs in immunotherapy. Biomaterials 34, 7840-7850. doi:10.1016/j.biomaterials.2013.06.050

Dang, Z. and Lowik, C. (2005). Removal of serum factors by charcoal treatment promotes adipogenesis via a MAPK-dependent pathway. Mol Cell Biochem 268, 159-167. doi:10.1007/s11010-005-3857-7

Das, M., Molnar, P., Devaraj, H. et al. (2003). Electrophysiological and morphological characterization of rat embryonic motoneurons in a defined system. Biotechnol Prog 19, 17561761. doi:10.1021/bp0340761
Das, M., Molnar, P., Gregory, C. et al. (2004). Long-term culture of embryonic rat cardiomyocytes on an organosilane surface in a serum-free medium. Biomaterials 25, 5643-5647. doi:10.1016/j.biomaterials.2004.01.020

Das, M., Gregory, C. A., Molnar, P. et al. (2006). A defined system to allow skeletal muscle differentiation and subsequent integration with silicon microstructures. Biomaterials 27, 4374-4380. doi:10.1016/j.biomaterials.2006.03.046

Das, M., Rumsey, J., Gregory, C. et al. (2007a). Embryonic motoneuron-skeletal muscle co-culture in a defined system. Neuroscience 146, 481-488. doi:10.1016/j. neuroscience.2007.01.068

Das, M., Wilson, K., Molnar, P. and Hickman, J. J. (2007b). Differentiation of skeletal muscle and integration of myotubes with silicon microstructures using serum-free medium and a synthetic silane substrate. Nat Protoc 2, 1795-1801. doi:10.1038/nprot.2007.229

Das, M., Rumsey, J. W., Bhargava, N. et al. (2009). Developing a novel serum-free cell culture model of skeletal muscle differentiation by systematically studying the role of different growth factors in myotube formation. In Vitro Cell Dev Biol Anim 45, 378-387. doi:10.1007/s11626-009-9192-7

De Brugerolle, A. (2007). Skinethic laboratories, a company devoted to develop and produce in vitro alternative methods to animal use. ALTEX 24, 167-171. doi:10.14573/ altex.2007.3.167

DePalma, A. (2016). Confluent trends in cell culture media. Genet Eng Biotechn 36, 16-19.

Dietrich, W., Gaba, A., Zhegu, Z. et al. (2011). Testosterone dependent androgen receptor stabilization and activation of cell proliferation in primary human myometrial microvascular endothelial cells. Fertil Steril 95, 1247-1255. doi:10.1016/j. fertnstert.2010.11.012

Dormont, D. (1999). Transmissible spongiform encephalopathy agents and animal sera. Dev Biol Stand 99, 25-34.

Doucet, C., Ernou, I., Zhang, Y. et al. (2005). Platelet lysates promote mesenchymal stem cell expansion: A safety substitute for animal serum in cell-based therapy applications. $J$ Cell Physiol 205, 228-236. doi:10.1002/jcp.20391

Doughman, D. J. and Rogers, C. C. (2012). Eye banking in the $21^{\text {st }}$ century: How far have we come? Are we prepared for what's ahead? Int J Eye Bank 1, 1-15. doi:10.7706/ijeb. v1i1.41

Eastment, C. T. and Sirbasku, D. A. (1980). Human platelet lysate contains growth factor activities for established cell lines derived from various tissues of several species. In Vitro 16, 694-705. doi:10.1007/BF02619199

Eggert, S., Alexander, F. and Wiest, J. (2015). An automated microphysiological assay for toxicity evaluation. Conf Proc IEEE Eng Med Biol Soc 2015, 2175-2178. doi:10.1109/ EMBC.2015.7318821

Ehleringer, J. R., Bowen, G. J., Chesson, L. A. et al. (2008). Hydrogen and oxygen isotope ratios in human hair are related to geography. Proc Natl Acad Sci U S A 105, 2788-2793. doi:10.1073/pnas.0712228105

EC - European Commission (2006). Regulation no 1907/2006 
on registration, evaluation, authorisation and restriction of chemicals (REACH). http://eur-lex.europa.eu/legalcontent/EN/TXT/?uri=CELEX\%3A02006R1907-20140410 (accessed 02.20.2017).

EC (2009). Regulation no $1223 / 2009$ on cosmetic products. http://eur-lex.europa.eu/legal-content/EN/TXT/ ?qid=1487602624201\&uri=CELEX:32009R1223 (accessed $02.20 .2017)$.

EMA (2011). Note for guidance on minimising the risk of transmitting animal spongiform encephalopathy agents via human and veterinary medicinal products (EMA/410/01 rev.3). http://www.ema.europa.eu/docs/en_GB/document_library/ Scientific_guideline/2009/09/WC500003700.pdf (accessed 02.21.2017).

EMA (2013). Guideline on the use of bovine serum in the manufacture of human biological medicinal products. http://www.ema.europa.eu/docs/en_GB/document_library/ Scientific_guideline/2013/06/WC500143930.pdf (accessed 08.03.2017).

ESAC (2008). ESAC statement on the use of FCS and other animal-derived supplements. https://eurl-ecvam.jrc. ec.europa.eu/about-ecvam/scientific-advice-stakeholdersnetworks/ecvam-scientific-advisory-committee-esac/ statements-opinions (accessed 04.18.2017).

Esch, M. B., Ueno, H., Applegate, D. R. and Shuler, M. L. (2016). Modular, pumpless body-on-a-chip platform for the co-culture of GI tract epithelium and 3D primary liver tissue. Lab Chip 16, 2719-2729. doi:10.1039/C6LC00461J

EU - European Union (2010). Directive no 2010/63/EU on the protection of animals used for scientific purposes. http://eur-lex.europa.eu/legal-content/EN/TXT/?uri= CELEX\%3A32010L0063 (accessed 02.20.2017).

Even, M. S., Sandusky, C. B. and Barnard, N. D. (2006). Serum-free hybridoma culture: Ethical, scientific and safety considerations. Trends Biotechnol 24, 105-108. doi:10.1016/j. tibtech.2006.01.001

Fekete, N., Gadelorge, M., Fürst, D. et al. (2012). Platelet lysate from whole blood-derived pooled platelet concentrates and apheresis-derived platelet concentrates for the isolation and expansion of human bone marrow mesenchymal stromal cells: Production process, content and identification of active components. Cytotherapy 14, 540-554. doi:10.3109/1465324 9.2012.655420

Flamand, N., Marrot, L., Belaidi, J. et al. (2006). Development of genotoxicity test procedures with episkin ${ }^{\circledR}$, a reconstructed human skin model: Towards new tools for in vitro risk assessment of dermally applied compounds? Mutat Res Fundam Mol Mech Mutagen 606, 39-51. doi:10.1016/j. mrgentox.2006.02.009

Fortunato, T. M., Beltrami, C., Emanueli, C. et al. (2016). Platelet lysate gel and endothelial progenitors stimulate microvascular network formation in vitro: Tissue engineering implications. Sci Rep 6, 25326. doi:10.1038/srep25326

Freedman, L. P., Gibson, M. C., Ethier, S. P. et al. (2015). Reproducibility: Changing the policies and culture of cell line authentication. Nat Methods 12, 493-497. doi:10.1038/ nmeth.3403

Freshney, R. I. (2005). Defined media and supplements. Culture of Animal Cells: A Manual of Basic Technique and Specialized Applications. $6^{\text {th }}$ edition. Hoboken, NJ, USA: John Wiley \& Sons, Inc. doi:10.1002/0471747599.cac009

Geraghty, R., Capes-Davis, A., Davis, J. et al. (2014). Guidelines for the use of cell lines in biomedical research. $\mathrm{Br} J$ Cancer 111, 1021-1046. doi:10.1038/bjc.2014.166

Gospodarowicz, D. and Ill, C. R. (1980). Do plasma and serum have different abilities to promote cell growth? Proc Natl Acad Sci U S A 77, 2726-2730. doi:10.1073/pnas.77.5.2726

Gottipamula, S., Ashwin, K., Muttigi, M. S. et al. (2014). Isolation, expansion and characterization of bone marrow-derived mesenchymal stromal cells in serum-free conditions. Cell Tissue Res 356, 123-135. doi:10.1007/s00441-013-1783-7

Groothuis, F. A., Heringa, M. B., Nicol, B. et al. (2015). Dose metric considerations in in vitro assays to improve quantitative in vitro-in vivo dose extrapolations. Toxicology 332, 30-40. doi:10.1016/j.tox.2013.08.012

Gstraunthaler, G. J. (1988). Epithelial cells in tissue culture. Ren Physiol Biochem 11, 1-42. doi:10.1159/000173147

Gstraunthaler, G. (2003). Alternatives to the use of fetal bovine serum: Serum-free cell culture. ALTEX 20, 275-81. http:// www.altex.ch/resources/Altex_2003_4_275_281_ Gstraunthaler.pdf

Gstraunthaler, G., Rauch, C. and Feifel, E. (2012). Human platelet lysates as a serum substitute in renal epithelial cell culture. FASEB J 26, Suppl, 1152.12-1152.12.

Gstraunthaler, G. and Lindl, T. (2013). Zell- und Gewebekultur: Allgemeine Grundlagen und spezielle Anwendungen. $7^{\text {th }}$ edition. Heidelberg, Germany: Springer-Verlag. doi:10.1007/978-3-642-35997-2

Gstraunthaler, G., Lindl, T. and van der Valk, J. (2013). A plea to reduce or replace fetal bovine serum in cell culture media. $C y$ totechnology 65, 791-793. doi:10.1007/s10616-013-9633-8

Gstraunthaler, G., Lindl, T. and van der Valk, J. (2014). A severe case of fraudulent blending of fetal bovine serum strengthens the case for serum-free cell and tissue culture applications. Altern Lab Anim 42, 207-209.

Gstraunthaler, G., Rauch, C., Feifel, E. and Lindl, T. (2015). Preparation of platelet lysates for mesenchymal stem cell culture media. J Stem Cells Res Rev Rep 2, 1021.

Guo, X., Das, M., Rumsey, J. et al. (2010). Neuromuscular junction formation between human stem-cell-derived motoneurons and rat skeletal muscle in a defined system. Tissue Eng Part C Methods 16, 1347-1355. doi:10.1089/ten. tec.2010.0040

Guo, X., Gonzalez, M., Stancescu, M. et al. (2011). Neuromuscular junction formation between human stem cell-derived motoneurons and human skeletal muscle in a defined system. Biomaterials 32, 9602-9611. doi:10.1016/j.biomaterials.2011.09.014

Guo, X., Spradling, S., Stancescu, M. et al. (2013). Derivation of sensory neurons and neural crest stem cells from hu- 
man neural progenitor hNP1. Biomaterials 34, 4418-4427. doi:10.1016/j.biomaterials.2013.02.061

Guo, X., Greene, K., Akanda, N. et al. (2014). In vitro differentiation of functional human skeletal myotubes in a defined system. Biomater Sci 2, 131-138. doi:10.1039/C3BM60166H

Hahne, M. and Reichl, S. (2011). Development of a serum-free human cornea construct for in vitro drug absorption studies: The influence of varying cultivation parameters on barrier characteristics. Int $J$ Pharm 416, 268-279. doi:10.1016/j.ijpharm.2011.07.004

Ham, R. (1963). An improved nutrient solution for diploid Chinese hamster and human cell lines. Exp Cell Res 29, 515-526. doi:10.1016/S0014-4827(63)80014-2

Ham, R. G. (1965). Clonal growth of mammalian cells in a chemically defined, synthetic medium. Proc Natl Acad Sci U S A 53, 288-293. doi:10.1073/pnas.53.2.288

Hara, Y., Steiner, M. and Baldini, M. G. (1980). Platelets as a source of growth-promoting factor(s) for tumor cells. Cancer Res 40, 1212-1216.

Harati, K., Daigeler, A., Hirsch, T. et al. (2016). Tumor-associated fibroblasts promote the proliferation and decrease the doxorubicin sensitivity of liposarcoma cells. Int $\mathrm{J} \mathrm{Mol} \mathrm{Med}$ 37, 1535-1541. doi:10.3892/ijmm.2016.2556

Haverty, P. M., Lin, E., Tan, J. et al. (2016). Reproducible pharmacogenomic profiling of cancer cell line panels. Nature 533, 333-337. doi:10.1038/nature17987

Hawkes, P. W. (2015). Fetal bovine serum: Geographic origin and regulatory relevance of viral contamination. Bioresour Bioprocess 2, 1-5. doi:10.1186/s40643-015-0063-7

Hemeda, H., Giebel, B. and Wagner, W. (2014). Evaluation of human platelet lysate versus fetal bovine serum for culture of mesenchymal stromal cells. Cytotherapy 16, 170-180. doi:10.1016/j.jcyt.2013.11.004

Hodgson, J. (1991). Checking sources: The serum supply secret. Nat Biotechnol 9, 1320-1324. doi:10.1038/nbt1291-1320

Hodgson, J. (1993). Fetal bovine serum revisited. A year ago serum regulations were a hodgepodge. Has anything changed? Biotechnology 11, 49-53. doi:10.1038/nbt0193-49

Hodgson, J. (1995). To treat or not to treat: That is the question for serum. Biotechnology 13, 333-343. doi:10.1038/nbt0495333

ISIA (2016). ISIA traceability certification. http://www. serumindustry.org/traceability.htm (accessed 02.21.2017).

ISO (2017). ISO 10993-5:2009. Biological evaluation of medical devices - Part 5: Tests for in vitro cytotoxicity. http:// www.iso.org/iso/catalogue_detail.htm?csnumber $=36406$ (accessed 02.21.2017).

Jayme, D. W. (1999). An animal origin perspective of common constituents of serum-free medium formulations. Dev Biol Stand 99, 181-187.

Jochems, C. E., van der Valk, J. B., Stafleu, F. R. and Baumans, V. (2002). The use of fetal bovine serum: Ethical or scientific problem? Altern Lab Anim 30, 219-227.

Johansson, L., Klinth, J., Holmqvist, O. and Ohlson, S. (2003). Platelet lysate: A replacement for fetal bovine serum in animal cell culture? Cytotechnology 42, 67. doi:10.1023/ B:CYTO.0000009820.72920.cf

Jonsdottir-Buch, S. M., Sigurgrimsdottir, H., Lieder, R. and Sigurjonsson, O. E. (2015). Expired and pathogen-inactivated platelet concentrates support differentiation and immunomodulation of mesenchymal stromal cells in culture. Cell Transplant 24, 1545-1554. doi:10.3727/096368914X683043

Jukić, S., Bubenik, D., Pavlović, N. et al. (2016). Adaptation of $\mathrm{CHO}$ cells in serum-free conditions for erythropoietin production: Application of EVOP technique for process optimization. Biotechnol Appl Biochem 63, 633-641. doi:10.1002/ bab. 1468

Karnieli, O., Friedner, O. M., Allickson, J. G. et al. (2017). A consensus introduction to serum replacements and serum-free media for cellular therapies. Cytotherapy 19, 155-169. doi:10.1016/j.jcyt.2016.11.011

Kasai, F., Hirayama, N., Ozawa, M. et al. (2016). Changes of heterogeneous cell populations in the Ishikawa cell line during long-term culture: Proposal for an in vitro clonal evolution model of tumor cells. Genomics 107, 259-266. doi:10.1016/j. ygeno.2016.04.003

Katoh, M., Hamajima, F., Ogasawara, T. and Hata, K. (2009). Assessment of human epidermal model LabCyte EPI-MODEL for in vitro skin irritation testing according to European Centre for the Validation of Alternative Methods (ECVAM)-validated protocol. J Toxicol Sci 34, 327-334. doi:10.2131/jts.34.327

Katoh, M., Hamajima, F., Ogasawara, T. and Hata, K. (2010). Assessment of the human epidermal model LabCyte EPI-MODEL for in vitro skin corrosion testing according to the OECD test guideline 431. J Toxicol Sci 35, 411-417. doi: $10.2131 /$ jts. 35.411

Kinzebach, S., Dietz, L., Klüter, H. et al. (2013). Functional and differential proteomic analyses to identify platelet derived factors affecting ex vivo expansion of mesenchymal stromal cells. BMC Cell Biol 14, 48. doi:10.1186/1471-2121-14-48

Kocaoemer, A., Kern, S., Klüter, H. and Bieback, K. (2007). Human $\mathrm{AB}$ serum and thrombin-activated platelet-rich plasma are suitable alternatives to fetal calf serum for the expansion of mesenchymal stem cells from adipose tissue. Stem Cells 25, 1270-1278. doi:10.1634/stemcells.2006-0627

Kramer, N. I., Hermens, J. L. and Schirmer, K. (2009). The influence of modes of action and physicochemical properties of chemicals on the correlation between in vitro and acute fish toxicity data. Toxicol In Vitro 23, 1372-1379. doi:10.1016/j. tiv.2009.07.029

Lee, J. G. and Kay, E. P. (2006). FGF-2-mediated signal transduction during endothelial mesenchymal transformation in corneal endothelial cells. Exp Eye Res 83, 1309-1316. doi:10.1016/j.exer.2006.04.007

Liebsch, M., Traue, D., Barrabas, C. et al. (2000). The ECVAM prevalidation study on the use of EpiDerm for skin corrosivity testing. Altern Lab Anim 28, 371-402.

Lucarelli, E., Beccheroni, A., Donati, D. et al. (2003). Platelet-derived growth factors enhance proliferation of human 
stromal stem cells. Biomaterials 24, 3095-3100. doi:10.1016/ S0142-9612(03)00114-5

Ludwig, T. E., Levenstein, M. E., Jones, J. M. et al. (2006). Derivation of human embryonic stem cells in defined conditions. Nat Biotechnol 24, 185-187. doi:10.1038/nbt1177

Mannello, F. and Tonti, G. A. (2007). Concise review: No breakthroughs for human mesenchymal and embryonic stem cell culture: Conditioned medium, feeder layer, or feeder-free; medium with fetal calf serum, human serum, or enriched plasma; serum-free, serum replacement nonconditioned medium, or ad hoc formula? All that glitters is not gold! Stem Cells 25, 1603-1609. doi:10.1634/stemcells.2007-0127

Marx, U., Andersson, T. B., Bahinski, A. et al. (2016). Biology-inspired microphysiological system approaches to solve the prediction dilemma of substance testing. ALTEX 33, 272321. doi:10.14573/altex.1603161

Maurer, H. (1986). Towards chemically-defined, serum-free media for mamalian cell culture. In R. Freshney (ed.), Animal Cell Culture: A Practical Approach (13-31). Oxford, UK: IRL Press.

Mellor, D. J., Diesch, T. J., Gunn, A. J. and Bennet, L. (2005). The importance of 'awareness' for understanding fetal pain. Brain Res Rev 49, 455-471. doi:10.1016/j.brainresrev.2005.01.006

Mojica-Henshaw, M. P., Morris, J., Kelley, L. et al. (2013). Serum-converted platelet lysate can substitute for fetal bovine serum in human mesenchymal stromal cell cultures. Cytotherapy 15, 1458-1468. doi:10.1016/j.jcyt.2013.06.014

Morgan, J. F., Morton, H. J. and Parker, R. C. (1950). Nutrition of animal cells in tissue culture; initial studies on a synthetic medium. Proc Soc Exp Biol Med 73, 1-8. doi:10.3181/0037972773-17557

Natarajan, A., Molnar, P., Sieverdes, K. et al. (2006). Microelectrode array recordings of cardiac action potentials as a high throughput method to evaluate pesticide toxicity. Toxicol In Vitro 20, 375-381. doi:10.1016/j.tiv.2005.08.014

Natarajan, A., Stancescu, M., Dhir, V. et al. (2011). Patterned cardiomyocytes on microelectrode arrays as a functional, high information content drug screening platform. Biomaterials 32, 4267-4274. doi:10.1016/j.biomaterials.2010.12.022

Nikolakis, G., Seltmann, H., Hossini, A. M. et al. (2015). Ex vivo human skin and SZ95 sebocytes exhibit a homoeostatic interaction in a novel coculture contact model. Exp Dermatol 24, 497-502. doi:10.1111/exd.12712

OECD - Organisation for Economic Co-operation and Development (2015a). Test no. 439: In vitro skin irritation: Reconstructed human epidermis test method. doi:10.1787/ 9789264242845-en

OECD (2015b). Test no. 492: Reconstructed human cornea-like epithelium (RhCE) test method for identifying chemicals not requiring classification and labelling for eye irritation or serious eye damage. doi:10.1787/9789264242548-en

OECD (2016). Test no. 431: In vitro skin corrosion: Reconstructed human epidermis (RHE) test method. doi:10.1787/ 9789264264618-en

Oleaga, C., Bernabini, C., Smith, A. S. et al. (2016). Multi-or- gan toxicity demonstration in a functional human in vitro system composed of four organs. Sci Rep 6, 20030. doi:10.1038/ srep20030

Ozturk, S. (ed.), Hu, W., Burgner, A. et al. (2005). Cell Culture Technology for Pharmaceutical and Cell-Based Therapies. Boca Raton, USA: CRC Press. doi:10.1201/9780849351068

Pamies, D., Bal-Price, A., Simeonov, A. et al. (2017). Good cell culture practice for stem cells and stem-cell-derived models. ALTEX 34, 95-132. doi:10.14573/altex.1607121

Parekh, M., Ferrari, S., Sheridan, C. et al. (2016). Concise review: An update on the culture of human corneal endothelial cells for transplantation. Stem Cell Transl Med 5, 258-264. doi:10.5966/sctm.2015-0181

Peter, J. F., Otto, A. M. and Wolf, B. (2007). Enrichment and detection of molecules secreted by tumor cells using magnetic reversed-phase particles and LC-MALDI-TOF-MS. J Biomol Tech 18, 287.

Pietersz, R., Reesink, H., Panzer, S. et al. (2014). Bacterial contamination in platelet concentrates. Vox Sang 106, 256-283. doi:10.1111/vox.12098

Pistollato, F., Bremer-Hoffmann, S., Healy, L. et al. (2012). Standardization of pluripotent stem cell cultures for toxicity testing. Expert Opin Drug Metab Toxicol 8, 239-257. doi:10. 1517/17425255.2012.639763

Post, M. J. (2012). Cultured meat from stem cells: Challenges and prospects. Meat Sci 92, 297-301. doi:10.1016/j. meatsci.2012.04.008

Puck, T., Cieciura, S. and Robinson, A. (1958). Genetics of somatic mammalian cells III. Long-term cultivation of euploid cells from human and animal subject. J Exp Med 108, 945956. doi:10.1084/jem.108.6.945

Puts, R., Albers, J., Kadow-Romacker, A. et al. (2016). Influence of donor age and stimulation intensity on osteogenic differentiation of rat mesenchymal stromal cells in response to focused low-intensity pulsed ultrasound. Ultrasound Med Biol 42, 2965-2974. doi:10.1016/j.ultrasmedbio.2016.08.012

Quentmeier, H., Amini, R. M., Berglund, M. et al. (2013). U-2932: Two clones in one cell line, a tool for the study of clonal evolution. Leukemia 27, 1155-1164. doi:10.1038/ leu.2012.358

Rakian, R., Block, T. J., Johnson, S. M. et al. (2015). Native extracellular matrix preserves mesenchymal stem cell "stemness" and differentiation potential under serum-free culture conditions. Stem Cell Res Ther 6, 235. doi:10.1186/s13287015-0235-6

Rauch, C., Feifel, E., Amann, E. et al. (2011). Alternatives to the use of fetal bovine serum: Human platelet lysates as a serum substitute in cell culture media. ALTEX 28,305. doi:10.14573/ altex.2011.4.305

Rauschenberger, L., Staar, D., Thom, K. et al. (2016). Exosomal particles secreted by prostate cancer cells are potent mRNA and protein vehicles for the interference of tumor and tumor environment. Prostate 76, 409-424. doi:10.1002/ pros. 23132

Rieck, P. W., Gigon, M., Jaroszewski, J. et al. (2003). Increased 
endothelial survival of organ-cultured corneas stored in FGF-2-supplemented serum-free medium. Invest Ophthalmol Vis Sci 44, 3826-3832. doi:10.1167/iovs.02-0601

Rodrigues, M. E., Costa, A. R., Henriques, M. et al. (2012). Comparison of commercial serum-free media for CHO-K1 cell growth and monoclonal antibody production. Int $J$ Pharm 437, 303-305. doi:10.1016/j.ijpharm.2012.08.002

Rougier, A. and Schaefer, H. (eds.) (1998). Protection of the Skin Against Ultraviolet Radiations. Paris, France: John Libbey Eurotext.

Rumsey, J. W., Das, M., Bhalkikar, A. et al. (2010). Tissue engineering the mechanosensory circuit of the stretch reflex arc: Sensory neuron innervation of intrafusal muscle fibers. Biomaterials 31, 8218-8227. doi:10.1016/j. biomaterials.2010.07.027

Rumsey, J. W., McAleer, C., Das, M. et al. (2013). Myelination and node of ranvier formation on sensory neurons in a defined in vitro system. In Vitro Cell Dev Biol Anim 49, 608-618. doi:10.1007/s11626-013-9647-8

Sarmento, B. (2015). Concepts and Models for Drug Permeability Studies: Cell and Tissue Based In Vitro Culture Models. Woodhead Publishing.

Schaffner, A. E., Barker, J. L., Stenger, D. A. and Hickman, J. J. (1995). Investigation of the factors necessary for growth of hippocampal neurons in a defined system. $J$ Neurosci Meth 62, 111-119. doi:10.1016/0165-0270(95)00063-1

Schallmoser, K., Bartmann, C., Rohde, E. et al. (2007). Human platelet lysate can replace fetal bovine serum for clinical-scale expansion of functional mesenchymal stromal cells. Transfusion 47, 1436-1446. doi:10.1111/j.15372995.2007.01220.x

Schallmoser, K., Rohde, E., Reinisch, A. et al. (2008). Rapid large-scale expansion of functional mesenchymal stem cells from unmanipulated bone marrow without animal serum. Tissue Eng Part C Methods 14, 185-196. doi:10.1089/ten. tec. 2008.0060

Schlingensiepen, K., Jaschinski, F., Lang, S. A. et al. (2011). Transforming growth factor-beta 2 gene silencing with trabedersen (AP 12009) in pancreatic cancer. Cancer Sci 102, 1193-1200. doi:10.1111/j.1349-7006.2011.01917.x

Shahdadfar, A., Frønsdal, K., Haug, T. et al. (2005). In vitro expansion of human mesenchymal stem cells: Choice of serum is a determinant of cell proliferation, differentiation, gene expression, and transcriptome stability. Stem Cells 23, 1357-1366. doi:10.1634/stemcells.2005-0094

Sheasgreen, J., Kubilus, J., Sennott, H. et al. (1996). Reproducibility and correlation of EpiOcular, a three-dimensional tissue culture model of the human corneal epithelium. Toxicologist 30, 128.

Shih, D. T., Chen, J., Chen, W. et al. (2011). Expansion of adipose tissue mesenchymal stromal progenitors in serum-free medium supplemented with virally inactivated allogeneic human platelet lysate. Transfusion 51, 770-778. doi:10.1111/ j.1537-2995.2010.02915.x

Shih, D. T. and Burnouf, T. (2015). Preparation, quality criteria, and properties of human blood platelet lysate supplements for ex vivo stem cell expansion. New Biotechnol 32, 199-211. doi:10.1016/j.nbt.2014.06.001

Siegel, W. and Foster, L. (2013). Fetal bovine serum: The impact of geography. BioProcess $J$ 12, 28-30. doi:10.12665/ J123.Siegel

Sikora, M. J., Johnson, M. D., Lee, A. V. and Oesterreich, S. (2016). Endocrine response phenotypes are altered by charcoal-stripped serum variability. Endocrinology 157, 37603766. doi:10.1210/en.2016-1297

Smith, A., Long, C., Pirozzi, K. and Hickman, J. (2013). A functional system for high-content screening of neuromuscular junctions in vitro. Technology 1, 37-48. doi:10.1142/ S2339547813500015

Smith, V. A. and Johnson, T. K. (2012). Identification and evaluation of a thinning agent compatible with MegaCell DCS, an animal product-free corneal storage medium. Graef Arch Clin Exp 250, 1777-1786. doi:10.1007/s00417-012-2126-1

Srinivasan, B., Kolli, A. R., Esch, M. B. et al. (2015). TEER measurement techniques for in vitro barrier model systems. J Lab Autom 20, 107-126. doi:10.1177/2211068214561025

Ståhle, M., Carlsson, B., Le Blanc, K. et al. (2010). Photochemical pathogen inactivation of human serum enables its largescale application in clinical cell transplantation. Vox Sang 98, e364-e365. doi:10.1111/j.1423-0410.2009.01257.x

Stancescu, M., Molnar, P., McAleer, C. W. et al. (2015). A phenotypic in vitro model for the main determinants of human whole heart function. Biomaterials 60, 20-30. doi:10.1016/j. biomaterials.2015.04.035

Sung, J. H., Esch, M. B., Prot, J. et al. (2013). Microfabricated mammalian organ systems and their integration into models of whole animals and humans. Lab Chip 13, 1201-1212. doi: $10.1039 / \mathrm{c} 31 \mathrm{c} 41017 \mathrm{j}$

Tan, K. Y., Teo, K. L., Lim, J. F. et al. (2015). Serum-free media formulations are cell line-specific and require optimization for microcarrier culture. Cytotherapy 17, 1152-1165. doi:10.1016/j.jcyt.2015.05.001

Tchang, L. A., Pippenger, B. E., Todorov, A. et al. (2015). Pooled thrombin-activated platelet-rich plasma: A substitute for fetal bovine serum in the engineering of osteogenic/vasculogenic grafts. J Tissue Eng Regen Med 11, 1542-1552. doi:10.1002/ term. 2054

Tekkatte, C., Gunasingh, G. P., Cherian, K. M. and Sankaranarayanan, K. (2011). "Humanized" stem cell culture techniques: The animal serum controversy. Stem Cells Int 2011, 504723. doi: $10.4061 / 2011 / 504723$

Thieme, D., Lindl, T., Kruse, F. E. and Fuchsluger, T. A. (2016). Evaluation of thrombocyte-based extract in different human corneal cell types. Invest Ophthalmol Vis Sci 57, 4925-4925.

Tonti, G. A. and Mannello, F. (2008). From bone marrow to therapeutic applications: Different behaviour and genetic/ epigenetic stability during mesenchymal stem cell expansion in autologous and foetal bovine sera? Int J Dev Biol 52, 10231032. doi: $10.1387 / \mathrm{ijdb} .082725 \mathrm{gt}$

USP (2012). US pharmacopeia manufacturing overview. http:// 
www.pharmacopeia.cn/v29240/usp29nf24s0_c1046s6.html (accessed 05.08.2017).

Usta, S. N., Scharer, C. D., Xu, J. et al. (2014). Chemically defined serum-free and xeno-free media for multiple cell lineages. Ann Transl Med 2, 97. doi:10.3978/j.issn.2305-5839.2014.09.05

van der Valk, J., Mellor, D., Brands, R. et al. (2004). The humane collection of fetal bovine serum and possibilities for serum-free cell and tissue culture. Toxicol In Vitro 18, 1-12. doi:10.1016/j.tiv.2003.08.009

van der Valk, J., Brunner, D., De Smet, K. et al. (2010). Optimization of chemically defined cell culture media - Replacing fetal bovine serum in mammalian in vitro methods. Toxicol In Vitro 24, 1053-1063. doi:10.1016/j.tiv.2010.03.016

Varghese, K., Das, M., Bhargava, N. et al. (2009). Regeneration and characterization of adult mouse hippocampal neurons in a defined in vitro system. J Neurosci Methods 177, 51-59. doi:10.1016/j.jneumeth.2008.09.022

Versteegen, R. (2016). Serum: What, when, and where? BioProcessing 15, 18-21. doi:10.12665/J151.Versteegen

Walenda, G., Hemeda, H., Schneider, R. K. et al. (2012). Human platelet lysate gel provides a novel three dimensional-matrix for enhanced culture expansion of mesenchymal stromal cells. Tissue Eng Part C Methods 18, 924-934. doi:10.1089/ ten.tec.2011.0541

Weiss, D., Brischwein, M., Grothe, H. et al. (2013). Label-free monitoring of whole cell vitality. Conf Proc IEEE Eng Med Biol Soc 2013, 1607-1610. doi:10.1109/EMBC.2013.6609823

Wessman, S. J. and Levings, R. L. (1999). Benefits and risks due to animal serum used in cell culture production. Dev Biol Stand 99, 3-8.

Wiest, J. (2016). A fetal bovine serum-free cytotoxicity test following ISO 10993-5. ALTEX Proc 5, 232. http://www.altex. ch/resources/Linz2016_Abstracts.pdf

Wiest, J., Namias, A., Pfister, C. et al. (2016). Data processing in cellular microphysiometry. IEEE Trans Biomed Eng 63, 2368-2375. doi:10.1109/TBME.2016.2533868
Wiest, J. (2017). Chemisch definiert - Ein zellbasierter Zytotoxizitätsassay ohne fötales Kälberserum. BIOspektrum 23, 61-62. doi:10.1007/s12268-017-0768-6

Yamasaki, S., Taguchi, Y., Shimamoto, A. et al. (2014). Generation of human induced pluripotent stem (Ips) cells in serum-and feeder-free defined culture and TGF- $\beta 1$ regulation of pluripotency. PLoS One 9, e87151. doi:10.1371/journal. pone.0087151

Yokoo, S., Yamagami, S., Usui, T. et al. (2008). Human corneal epithelial equivalents for ocular surface reconstruction in a complete serum-free culture system without unknown factors. Invest Ophthalmol Vis Sci 49, 2438-2443. doi:10.1167/ iovs.06-1448

\section{Conflict of interest}

$\mathrm{J}$. Wiest is shareholder and CEO of cellasys $\mathrm{GmbH}$.

\section{Acknowledgements}

The workshop and its report would not have been possible without the financial support of the Stiftung zur Förderung der Erforschung von Ersatz- und Ergänzungsmethoden zur Einschränkung von Tierversuchen (set Foundation) and the hospitality of the German Animal Welfare Federation.

\section{Correspondence to}

Jan van der Valk, PhD

3Rs-Centre ULS

Fac. Veterinary Medicine

Utrecht University

Yalelaan 2

3584 CM Utrecht, The Netherlands

Phone: +31 302532163

e-mail: j.vandervalk@uu.nl 